Article

\title{
Integrative Assessment of Land Use Conflicts
}

\author{
Zita Izakovičová ${ }^{1}$, László Miklós ${ }^{2}$ and Viktória Miklósová ${ }^{1, *}$ \\ 1 Institute of Landscape Ecology of Slovak Academy of Sciences, 81499 Bratislava, Slovakia; \\ zita.izakovicova@savba.sk \\ 2 Faculty of Ecology and Environmental Sciences, Technical University Zvolen, 96053 Zvolen, Slovakia; \\ miklos@tuzvo.sk \\ * Correspondence: viktoria.miklosova@savba.sk; Tel.: +421-2-3229-3624
}

Received: 31 July 2018; Accepted: 5 September 2018; Published: 13 September 2018

\begin{abstract}
Changes in land use are reflected primary in changes of land cover, but subsequently cause conflict of interest of sectors and are the main initiation of many environmental problems. The basic tool for sustainable utilization of the landscape is integrated landscape management, which, in our understanding, is the environmentally biased harmonization of tools which regulate the spatial organization and functional utilization of the landscape to avoid the conflicts of interest of sectors. "Integrated" in this case means the systematic assessment of the interests of all relevant sectors from the environmental point of view. The scientific base of this approach is the understanding of the landscape as a geosystem, and, in particular, the proper interpretation of the mutual relations of primary, secondary and tertiary landscape structures and their role in the assessment of the conflicts of interest. This paper presents a theoretical and methodical base for the integrated approach to the assessment of the conflicts of interest of the sectors in the landscape. The theoretical-methodical base was applied to the model territory of the Trnava district (south-west Slovakia). Mutual conflicts of interest of endangering and endangered sectors cause diverse problems, which were ranked in three basic groups as: problems of endangering of the ecological stability of the landscape (including endangering of biodiversity and nature conservation areas); problems of endangering of natural resources (in particular forests, soils, waters); and, problems of endangering the immediate human environment (stress factors in residential and recreational areas). The result is the identification and analysis of the conflicts of interest in the territory and their projection to a map. This research should be followed by implementation of procedures of ecologically optimal spatial organization and utilization of the territory for regular spatial planning processes.
\end{abstract}

Keywords: land use conflicts; encounters of interests; landscape as geosystem; integrative landscape management; Trnava district

\section{Introduction}

European countries in the recent period have faced many substantial socio-economic changes, which are also reflected in the environment [1]. Changes in land use are often linked to the occurrence of environmental problems-qualitative and quantitative degradation of natural resources, decline of natural ecosystems, negative impact of abandoned agricultural fields on biodiversity, desertion of land, increase of synanthropic species etc. [2]. Changes in landscape structure are the major causes of climatic change, which, in addition to changes to ecosystems, are increasingly intensifying natural risks and hazards, such as floods, droughts, erosion, accumulation, landslides and others [3].

Environmental issues related to changes in the landscape were also highlighted by the European Environmental Agency which specified a total of 11 global megatrends (GMTs) in four clusters that need to be addressed urgently [4]. Within the environmental cluster, these are growing pressure on ecosystems and natural resources, climate change and growing environmental pollution. The impacts 
of the GMTs are not yet completely known, as many have begun to manifest themselves in recent years. The relationships between individual GMTs raise a large number of questions, and there are still many deficiencies in the knowledge of their impact on the landscape.

Several of these environmental global megatrends are initiated by inappropriate land use. According to Food and Agriculture Organization of the Unated Nations (FAO) information, up to $60 \%$ of the world's ecosystems are degraded and exploited unsustainably [5]. In the EU, only $17 \%$ of habitats and species and $11 \%$ of key ecosystems protected by European legislation show a favorable status [4-6]. This is despite the adoption of measures in 2001 to combat biodiversity loss. All scenarios of global and regional assessments show that biodiversity loss, degradation of ecosystems and threats to environmental conditions will continue or even accelerate [7]. Human activities, global population growth and changing consumption patterns are key factors responsible for this growing environmental burden, which primarily becomes evident in land use changes.

Climate change and its negative impacts, such as negative changes of the water cycle, are also often tied to inappropriate land use. Inappropriate use of river basins, such as deforestation and intensive agricultural production contributes to rapid water drainage and consequently to natural hazards such as floods and drought [8].

To find the cause and casualties of these changes is the base for development and implementation of methods of optimal land use. A key approach for the analysis of these problems is the integrated approach to land use assessment [9].

Land use conflicts are usually assessed by analyses and statistical models of changes of areas of land cover. There is a significant amount of such research. This step is needed, but the mere comparison of changes on a given area in certain time only shows the encounters of one pair of activities. The presented integrated approach, supported by a matrix model, allows the analysis for the same area at the same time all existing and planned encounters of all relevant activities by assessments of the harmony of primary landscape structure (PLS), secondary landscape structure (SLS) and tertiary landscape structure (TLS) [10-12] and [13] (see Chapter 2.1.d). This approach includes the mutual comparison of the abiotic conditions (PLS), land cover including biotic elements (SLS), as well as the legal conditions and limits for development of a territory (TLS). These methods have been developed at the Institute of Landscape Ecology of the Slovak Academy of Sciences since the early 1980s (including by the authors), and applied to a number of concrete territories [14-21]. The approach is based on geosystem theory [22-25] applied to the needs of landscape ecological planning [12,26]. The methodology and the individual methods have been continually improved, incorporating new techniques, such as GIS, remote sensing and other computer techniques [26-28].

The aim of this paper is to present the methodology for the assessment of environmental land use conflicts, based on this integrative approach. Since the problems of the conflict of land use in our understanding arise from the mutual relation of all structures and components of the geographical sphere, the object of our assessment is the integrated system of a spatial section of the geosphere-the landscape as a geosystem [29-31]. Obviously, this integrated system also includes the elements of the land-cover which are result of the land-use. Therefore, in this article we use the term "conflict of interests in the landscape", which naturally also includes conflicts of land use.

\section{Materials and Methods}

\subsection{Theoretical Aspects of the Integrated Landscape Management}

The term "integrated" in land-use management incorporates an extremely broad scope of topics with different understandings. The integrated approach is a slogan often used in environmental politics. Nevertheless, it is not a new issue at all. The base aspects were defined in AGENDA 21 from Rio Summit 1992, in Chapter 10 "Integrated approach to the management of land resources". The main statements presented in this chapter-still valid and obvious-are as follows:

- Several sectors claim land for their activities in the same territory. 
- $\quad$ There is only one landscape space, which is to be accepted by each sector.

- $\quad$ Activities use the landscape, but are in conflict.

- Conflicts cause environmental, economic and other problems.

- To solve conflicts an integrated approach is needed for management of land resources [32].

Why use an integrated approach? The scientific basis is evident and quite simple: since the landscape is an integrated system of concrete spatial segments of the Earth, which integrate all material components of the landscape-such as the geological base, soil, water, relief, air, biota, and elements of man-influenced, man-altered and man-made land cover (i.e., the geosystem) —all changes to one single element of this system causes changes to all other elements. Both the space itself and the material elements are considered natural resources [30]. If one applies good management (e.g., for watershed protection), reducing biodiversity loss, soil erosion, and water pollution from agriculture and the microclimate can be achieved contemporaneously. Conversely, application of poor management may cause these problems.

These basic aspects presented by AGENDA 21 on an integrated approach were enhanced in a number of environmental-political documents [33-38].

To develop the integrative approach, keeping in mind the above-mentioned statements, we need to answer several basic questions, such as:

(a) Who manages the land and why are they in conflict?

The landscape is under the care/responsibility/management of different sectors, which realize their interests in the space, such as:

- forestry-manages the forests;

- $\quad$ agriculture-manages the agricultural land;

- water management-manages the waters and watersheds;

- nature conservation-manages the conservation areas and protected objects;

- recreation-manages the recreational activities and areas;

- urbanization and communal sphere-manages the built-up areas and communal areas;

- industry-manages the industrial areas.

The basic interest of these sectors is to fulfill their own goals, with less regard for other sectors; therefore, their activities can cause conflicts of interest, and, consequently, environmental and other problems.

Effective mitigation of these conflicts needs integrated landscape management [39-41].

(b) How are interests of a sector in the landscape realized and what is the best phase for integrative action in landscape management?

The process starts with a very basic question asked by humans: do we like the current structure of the landscape of a given territory? If so, we try to execute protective regulations to preserve its structure. More often, the case is that the development of society needs changes. In this case, the process (in civilized countries) follows the sequence: assessment of current situation, formulation of demands/interests/requests, planning/projecting, and realization/execution. All these steps are regulated by different institutional tools, such as economic and social conditions, legislation, methods, and normative and technical conditions [42].

Analyzing this process, it is obvious that the best chance to avoid conflicts of interests-that is, the best chance for harmonization of these interests (i.e., integration)—is in the early stages of the process. In practice, it is at the stage of planning.

Accordingly, land-use planning should act as one of the main tools of the integrated approach to the optimal spatial organization and functional utilization of landscape for all sectors. This is in line with the still-current provisions of AGENDA 21, which stated that integrated land-resource 
management needs integrated physical planning to act as a spatial frame and basis for each sectoral plan [32]. AGENDA 21 also defines the integration of environmental issues, such as:

"Government on the appropriate level ... should: Adopt planning and management systems that facilitate the integration of environmental components such as air, water, land and other natural resources, using landscape ecological planning (LANDEP) or other approaches that focus on, for example, ecosystem or a watershed."

Different countries adopt different approaches to the development of integrated planning tools [43-49]. These tools are marked with different terms, such as spatial planning, physical planning or land-use planning. In Slovakia, the most integrative tool which corresponds with the above-mentioned aspects of integration is so-called territorial planning ("územné plánovanie"), which, according to its legally defined provisions, should provide spatial organization and functional utilization

- of the whole territory without any missed areas;

- for all sectors requesting space in this territory.

Ecological aspects of territorial planning are present as landscape ecological planning and as the territorial system of ecological stability, both mentioned as obligatory regulations for each territorial plan [50].

(c) What is the integration of landscape management?

In our understanding, the integration of landscape management means the harmonization of the tools which regulate the spatial organization and functional utilization of the landscape [51]. It is to be underlined, also, that the term "management" means the ruling device, the chain of planning, organizing/regulating, and controlling. Accordingly, integrated landscape management is the ruling device for harmonization of the planning, regulating and controlling tools of the spatial organization and functional utilization of the landscape. To clarify, we do not consider execution of physical actions to be integrated management (i.e., in forestry, in the agriculture, in water-management etc.) because there is no integrated grass-cutting, integrated tillage along the contour lines, integrated timber harvest, building flood preventive objects, etc. These are simply physical actions, which are, of course, needed and can lead to desired effects; however, integrated management is the ruling policy forcing the users to provide such actions $[48,52-54]$.

(d) What is the material basis for integrated landscape management?

Management is executed in the landscape as a geosystem, which is an integrated system of the space, geo-relief and all other natural, man-influenced and man-made components of the landscape-material resources in certain area — such as the geological base, water, soil geo-relief, biotic components, climate, land-use, man-made objects and non-material socio-economic phenomena in the landscape, and their relationships [29-31,55]. Of special importance for evaluating the conflicts of interest in the landscape is the definition of three structures of the landscape according to their genesis, physical matter, possibility to change and their role in the management:

- $\quad$ Primary landscape structure (PLS): is a set of material elements of the landscape and their relationships that constitute the original foundation and condition for the other two structures. These are the abiotic elements-the geological base and subsoils, soils, waters, geo-relief, and air. The principles of their functions are not changeable. This aspect is decisive in evaluating and solving the conflicts of interest.

- Secondary landscape structure (SLS): is constituted by man-influenced, reshaped and created elements of land-cover, which is the result of land-use. Here also belong the elements of real biota, man-made objects and constructions. A very frequent case of the conflict of interest is the disharmony between land-use and primary landscape structure. 
- Tertiary landscape structure (TLS): is a set intangible (non-material) socio-economic factors/phenomena displayed to the landscape space as the interests, manifestations and consequences of the activities of individual sectors that are relevant to landscape. These are the protection and other functional zones of nature and natural resources protection, hygienic and safety zones of industrial and infrastructure objects, declared zones of specific environmental measures, administrative boundaries, etc. They are defined in acts, plans and other development documents. Since they are of non-material character they often overlap. This fact is one of the main causes of conflicts of interest.

Understanding the mutual relationships of the three different landscape structures is the theoretical basis for the evaluation and solution of the conflicts of interests in the landscape.

\subsection{Methodical Approach}

The method of the assessment of the interests of sectoral activities is based on the understanding of the landscape as a geosystem [29,56,57], in particular on the systematic interpretation of the mutual relationships of primary landscape structure (PLS), secondary landscape structure (SLS) and tertiary landscape structure (TLS). An elementary explanation of the relationships and roles of these structures in conflicts of interest is as follows.

The current use of the landscape-SLS—is conditioned by the features of the natural landscape structure-PLS - which represent a certain offer for the use of natural resources by humans. On the other hand, the use of the landscape is driven by the requirements, the demands, and the possibilities of using the natural resources by humans, as well as human's ability to protect and rationally exploit these sources, expressed by socio-economic factors and phenomena from the TLS. Needs, requirements, and options expressed by the TLS change over time (change of priorities, change of ownership relationships, change of technologies, change of socio-economic conditions, etc.). Changes in the claims and demands of society are consequently reflected in the change, forms and intensity of use of natural resources, expressed by the SLS. Changes can also be caused by the natural reaction of the PLS to the specific use of the landscape, if such use of the SLS is unsustainable. These are the negative impacts of inappropriate land use; for example, erosion processes, landslides, calamities, etc. If the use of the landscape SLS is not in accordance with the natural resources and potentials of the PLS, this leads to conflicts of interest and to environmental problems in the landscape.

The method comprises systematic evaluation of the spatial encounters of overlapping structures, where:

- $\quad$ The PLS represents the space and the material natural resources used by sectors.

- $\quad$ The SLS represents the current use of these resources.

- $\quad$ The TLS represents the regulations and legal provisions for use of these resources.

The method of assessment of the conflict of interests of the sectors in the landscape involves the following steps.

\subsubsection{Spatial Projection of the Interests of the Sectors to the Landscape Space}

In practice, this step means the spatial projection of relevant elements of all three landscape structures to maps. The PLS is represented by geological resources, water and soil resources; the SLS by land cover elements creating the characteristic landscape structure, including forests and other biotic elements; and the TLS by the displayed regulations of the use and protection of nature, natural resources and the environment. The map projection of these elements can be considered for display of the interests of the sectors to the landscape space.

The projected interests overlap in the space and thus creates an encounter of interests of very diverse characters. 


\subsubsection{Analyses, Syntheses and Evaluation of the Spatial Encounters of the Interests of the Sectors}

This is the crucial step of the method. The core of the method is the objective delimitation, analysis and listing of combinations of the overlapping elements of all three structures. These can be combinations of several elements.

The activities of sectors for the purposes of the evaluation of conflicts of interest can be assessed from environmental/ecological point of view as [58]:

- Having a positive impact on the landscape and ecosystems. These are activities aimed at nature and landscape protection (conservation areas of different degrees) and natural resources protection (protected zones of geological, soil, water and forest resources). According to the division of ecosystem services [59] these zones usually provide protection for ecosystems which provide supportive, and in some cases even productive services; for example, the protection of soil resources is primarily focused on the use of production functions on high quality soils. When these activities are encountered with activities of other sectors (mainly with productive sectors) their execution is in most cases endangered.

- Having a negative impact on the landscape and ecosystems. These are activities of the stress factors that aggravate the quantity and quality of the landscape as a whole, as well as individual natural resources and, at the same time, they limit the use of their ecosystem services. These are activities from the industry, energy, mining, transport, and urbanization sectors. Negative impacts of human activities are manifested by spatial reduction of the areas of natural and semi-natural ecosystems and natural resources, reducing the overall ecological stability of the landscape, creating barriers to natural biota movement, producing contaminants, and degrading the environment; for example, damaged forest ecosystems and agri-ecosystems have reduced economic value and limited use due to stress factors. Contaminated soil is not hygienically suitable for growing crops for direct consumption. When these activities are encountered with activities of other sectors (mainly with protective sectors) they have the characteristic of endangering factors [60].

- Several sectoral activities are of a two-fold character. On one side they are important, or even crucial, for the provision of a high-quality environment or natural resources; on other side their execution endangers the optimum use of land, natural resources and ecosystem services.

These sectors are:

Agriculture: Agriculture is a very specific sector. On one hand, it is obviously responsible for the protection of its own production resource-soil resources—but, on other hand, the effort to increase production causes over-exhaustion of soils, often degradation by pollution, drought by ameliorations, erosion, compaction with heavy machines, etc. So, agriculture is a specific example of an internal conflict of interest within the same sector.

Forest management: Forest resources are undeniably crucial for ecological stability, biodiversity and environment. These aspects of forests are defined by law as their non-productive functions, and in practice by delineation of special-purpose and protective forests. However, at the same time, forest management that is oriented on timber production is sometimes considered a main enemy of nature conservation, causing diverse problems for biodiversity loss, erosion, accumulation, pollution, etc.

Water management: This is the key sector responsible for good quality and quantity of water resources. The activities and duties of water management are defined by law and, in practice, projected as protective zones of water resources of different character. On the other hand, the technical activities of water management, such as building dams, regulation of rivers and creating technical measures against floods, are often evaluated as a danger; for example, when water reservoirs overlap precious biotopes, the flow destroys the natural living conditions for animals when the measures cause considerable lowering or rise of underground water levels.

Urbanization: Residential areas-including all necessary accessories such as parks and other green surfaces-are considered resources for fulfilling human needs. On the other hand, communal 
activities, such as waste and sewage management, as well as the rise of residential areas and the population itself, cause significant problems by overlapping agricultural land, pollution, garbage, and non-controlled activities of the population with nearby nature.

Recreation: Recreational areas, spas, health resorts and provided recreational activities are considered a natural resource for human health. On the other hand, intensive recreational activities often mean an intensive impact on nature; for example, ski resorts in high mountains, dense tourist paths in national parks, overpopulated recreation centers in natural parks, etc., cause changes and destruction of natural habitats, lowering the ecological stability of these natural resources.

\subsubsection{Assessment of the Character of Encounters of Interests}

The evaluation of the encounters of interests is processed in a matrix (Figure 1).

\begin{tabular}{|c|c|c|c|c|c|c|c|c|c|}
\hline $\begin{array}{l}\text { Endangering } \\
\text { Endangered }\end{array}$ & \begin{tabular}{|l|} 
Industry, \\
Energetics
\end{tabular} & \begin{tabular}{|l|} 
Mineral's \\
exploitation, \\
mining \\
\end{tabular} & Transport & Urbanisatio & Recreation & Agriculture & \begin{tabular}{|l|} 
Fonest \\
manage \\
ment
\end{tabular} & \begin{tabular}{|l|} 
Water \\
manageme \\
nt
\end{tabular} & $\begin{array}{l}\text { Type of } \\
\text { problems }\end{array}$ \\
\hline $\begin{array}{l}\text { Nature conservation } \\
\text { areas }\end{array}$ & & & & & & $\begin{array}{l}\text { Biodiversity } \\
\text { loss }\end{array}$ & & & \\
\hline $\begin{array}{l}\text { Other natural } \\
\text { landscapes }\end{array}$ & & & & & & $\begin{array}{l}\text { Lowering } \\
\text { ecological } \\
\text { stability }\end{array}$ & & & $\begin{array}{l}\text { Endangerng } \\
\text { the ecological } \\
\text { stability of } \\
\text { the landscape }\end{array}$ \\
\hline Forest resounces & & & & & & $\begin{array}{l}\text { Reduction of } \\
\text { forest aneas }\end{array}$ & & & \multirow{4}{*}{$\begin{array}{l}\text { Endangering } \\
\text { the natural } \\
\text { resources }\end{array}$} \\
\hline Water resounces & & & & & & $\begin{array}{l}\text { Pollution by } \\
\text { chemisation }\end{array}$ & & & \\
\hline Geological resources & & & & & & $\begin{array}{l}\text { Inproper } \\
\text { land use }\end{array}$ & & & \\
\hline Soil resources & $\begin{array}{l}\text { Land } \\
\text { areas } \\
\text { neduction, } \\
\text { pollution }\end{array}$ & Pollution & $\begin{array}{l}\text { Land areas } \\
\text { reduction, } \\
\text { pollution }\end{array}$ & $\begin{array}{l}\text { Land areas } \\
\text { reduction, } \\
\text { soil } \\
\text { degredation }\end{array}$ & $\begin{array}{l}\text { Lond and } \\
\text { cultures } \\
\text { degradatio } \\
n\end{array}$ & $\begin{array}{l}\text { Enosion, } \\
\text { accumulation } \\
\text { compaction }\end{array}$ & $\begin{array}{l}\text { Enosion, } \\
\text { accumul } \\
\text { ation, } \\
\text { floods }\end{array}$ & $\begin{array}{l}\text { Land areas } \\
\text { reduction, } \\
\text { water } \\
\text { logging }\end{array}$ & \\
\hline $\begin{array}{l}\text { Heath resources } \\
\text { (spa, recreational } \\
\text { areas) }\end{array}$ & & & & & & $\begin{array}{l}\text { Odour, dust, } \\
\text { alergens, } \\
\text { infections }\end{array}$ & & & \multirow{2}{*}{$\begin{array}{c}\text { Endangering } \\
\text { the human } \\
\text { environment }\end{array}$} \\
\hline $\begin{array}{l}\text { Resources of human } \\
\text { power (residential } \\
\text { aneas) }\end{array}$ & & & & & & $\begin{array}{l}\text { Odour, dust, } \\
\text { alergens, } \\
\text { infections }\end{array}$ & & & \\
\hline
\end{tabular}

Figure 1. Matrix of the encounters of interests in the landscape.

According to the above description of the sectoral activities, they are arranged in the matrix as follows:

- Rows of the matrix incorporate those sectoral activities which aim toward the protection and conservation of nature and landscape, protection of natural resources and human environment. From the ecological point of view these activities can be considered as endangered by other sectors.

- Columns of the matrix incorporate those sectoral activities which aim toward material production of goods and other technical services, such as industry, energy, mining, transport, urbanization, recreation, agriculture, forestry, and water management. From the ecological point of view these activities can be considered as endangering the sectors mentioned above.

- The squares of the matrix represent the encounters of the interests of the sectors. 
There are two ways for evaluating these encounters:

- By evaluation down the columns we ask: how does an endangering activity threaten the endangered factors? Figure 1 describes this mode using the example of the evaluation of how agriculture threatens the particular endangered factors.

- $\quad$ By evaluation along the rows we ask: how is an endangered factor threatened by endangering activities? Figure 1 presents this mode using the example of the evaluation of how soil resources are threatened by particular endangering activities.

These encounters represent several types of encounters and conflicts, such as:

(a) The overlap of productive sectors-mainly industry, energy, mining, transport and urbanization-with all other sectors represents real conflicts where the basic problem arises from the efforts of these sectors to broaden their respective territories. Thus, these sectoral activities change the land use, destroy biotopes and build barriers. This is the type of conflict when the sectors "fight" for land of other sectors.

(b) Some overlap/encounters of sectoral interests have mutually supporting effects; e.g., the overlap of special-purpose forests with nature conservation, or of water protective zones with protective forests. These overlaps are actually just spatial encounters in the same area, rather than conflicts. On the other hand, the overlapping of productive forests with national parks, for example, represents real environmental conflicts for nature conservation. The designation and exclusive use of high quality soils exclusively for agricultural production can be clearly considered for protection of soil resources but, conversely, the overlapping of these soils with water protective zones causes real conflict because of the impacts on waterways of chemicals used in intensive agriculture. These types of conflicts can be considered as the encounters and conflicts when several sectors execute their activities on the same territory.

(c) Few sectoral activities cause conflict with their own productive resources. These include the conflict of agricultural activities with the soil resources, or timber production activities with forest resources. This is the type of internal conflict of interest within the same sector.

(d) The productive sectors-industry, energy, transport, agriculture-also produce pollution of the air and water, which does not respect any spatial limits. They cause real conflicts with the human environment and health resources, as well as conflicts with water, soil and forest resources [61]. This is the type of real conflict of polluting activities with environment and natural resources.

A few other important aspects of the process of evaluation in the matrix in Figure 1 should also be mentioned:

- The matrix may be considered as a model (even qualitative) of all possible mutual conflicts of all sectors. Although the presented graphical form of the matrix in paper is two-dimensional, in a real territory there are encounters not only of pairs of endangered and endangering activities, but there may also be diverse combinations of several activities. So, the evaluation of encounters and conflicts is much more complex.

- In the present work we applied Geographic Information System (GIS) technology, which allows the assessment of the conflicts of several sectoral activities on the same area in a certain time, if they occur. Therefore, the matrix is actually multidimensional. GIS technology allows the analysis of each conflict of interest quantitatively, according to its area size, including the conflict of the land use (SLS) with natural conditions (PLS).

- In a real territory the general designations of the sectors, elements and factors are concretized and replaced by real existing elements of PLS, SLS and TLS (as an example, see the matrix on the Figure 8, Section 3.4). 
- Conflicts of land use were previously quantitatively documented by statistical data which mirror the changes of areas of land use. Methodologically, it is a simple procedure, and the literature includes many examples. However, these statistics document the changes, in a certain time period and a certain area, of pairs of land-use forms. The list of all binate changes can be considered as an integrated picture of the changes, but they remain simply a set of binate data. The present paper did not consider this method as a priority. The present paper describes the assessment of the mutual conflicts of all sectors, and, at the same time, the assessment of their relationships/conflicts with all three defined landscape structures. Thereafter, it also provides the characteristics of these conflict. These characteristics are qualitative. The evaluation and assessment of the characteristics of sectoral activities presented above is given from an environmental/ecological point of view. If the same encounter were assessed by an industrialist, an agriculturist or a forester, they would identify endangered and endangering activities differently. For example, ecologists consider timber production a significant threat to nature conservation; in contrast, foresters consider as an endangering factor something which threatens forestry, even nature conservation [62].

\subsubsection{Classification of the Problems Caused by Conflicts of Interest in the Landscape}

The evaluation of the conflicts of interest as described above allows a general classification of environmental problems caused by conflicts of interest in the landscape into three groups (see Figure 1) [58,63].

(a) Problems of endangering the ecological stability of the landscape

These problems arise as the consequence of the influence of stress factors to elements with high eco-stabilizing effects-nature conservation areas or other ecologically valuable areas of the landscape (forest, water areas, meadows, pastures, areas of public greenery etc.). These problems are represented in the first two rows of Figure 1.

(b) Problems of endangering the natural resources

These arise from spatial conflicts of stress factors and natural resources. The result of this conflict is deterioration of quality and quantity of natural resources. The most important problems in this category relate to endangering the territories with sources of drinking water, good quality soil, and productive forests. These problems are represented in the third, fourth, fifth and sixth rows of Figure 1.

(c) Problems of endangering the immediate human environment

These arise from the impact of stress factors on areas where people permanently reside (residential areas), or where they spend holidays or undergo medical treatment (recreational and health resorts). These problems are represented in the last two rows of Figure 1.

\subsection{Brief Description of the Model Territory}

The theoretical-methodical base described above was applied in the model territory of the Trnava district. This study area represents a typical agricultural landscape. The district is located in south-west Slovakia (Figure 2). Administratively, it consists of 45 rural settlements and the city of Trnava, which is also acting as the county's capital city. With an area of $741 \mathrm{~km}^{2}$, it belongs to a medium-sized district of Slovakia. In the region, there live 131,644 inhabitants and the average population density is 178 inhabitants per kilometer [64]. 


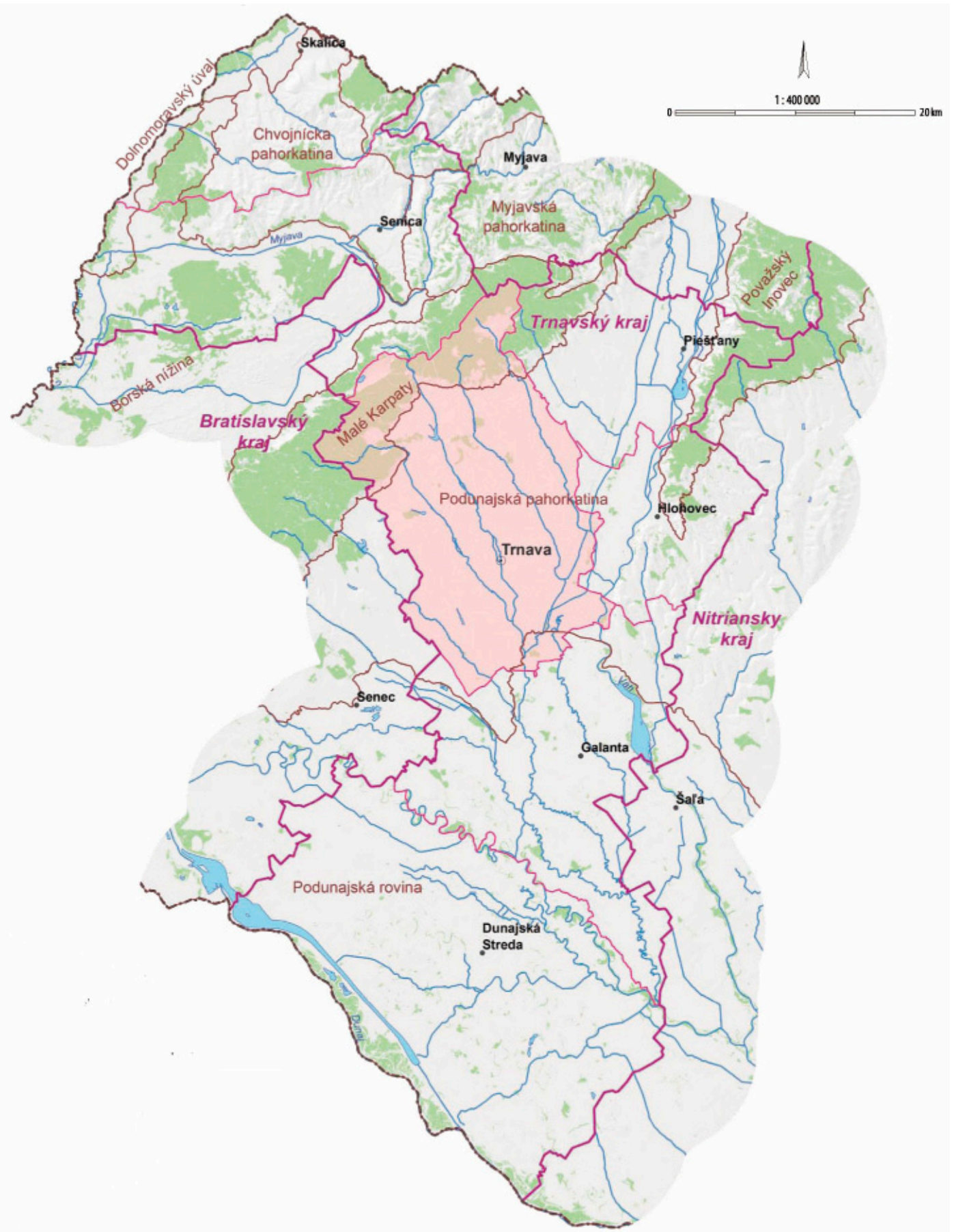

Figure 2. Situation map of the model territory (the Trnava district).

The dominant position in the landscape structure comprises agricultural land. Up to $93.1 \%$ of agricultural land is intensively utilized as big-block structured arable land. Arable land covers the central and southern parts of the area of interest. Cereals dominate in the utilization of arable land. Forest vegetation is unevenly distributed in the given area. Acreage of the forests is 24,874 ha, and $16.8 \%$ of the territory is predominantly concentrated in sub-mountain villages in the northern part of the area (Figure 3). The territory ties to the Little Carpathians Protected Landscape Area (PLA). 


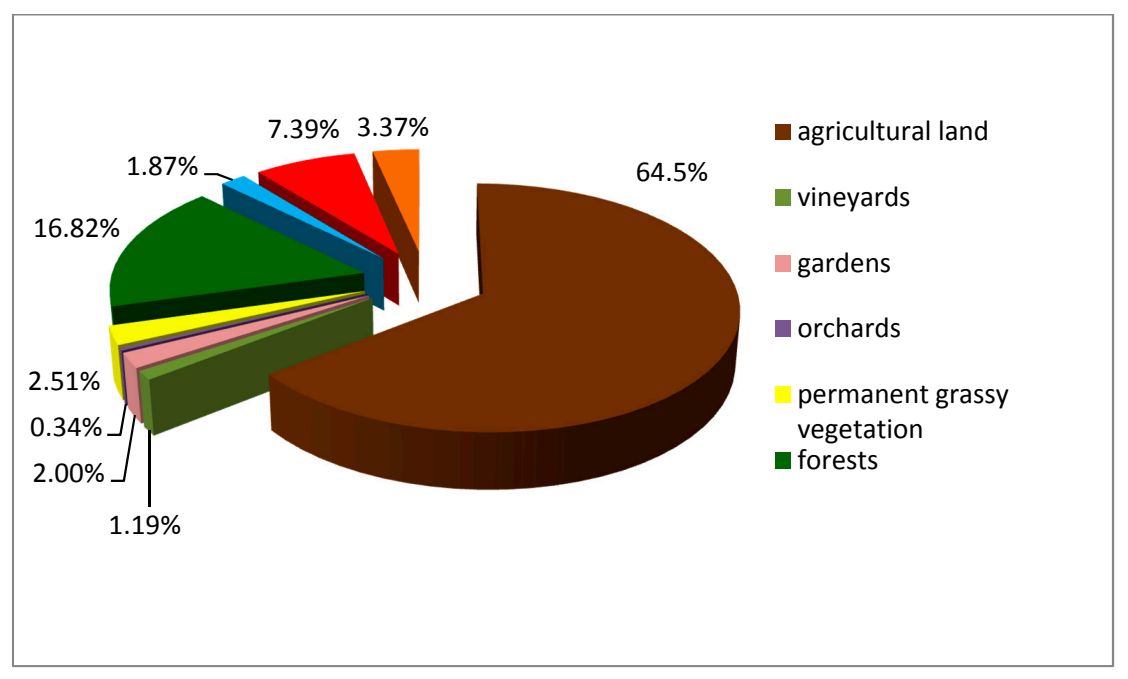

Figure 3. Land use in Trnava district in 2018 [64].

From a geomorphological point of view, the territory lies on Trnava loess plateau, the Danubian plain and the Little Carpathians mountains. The central and southern part belong to the Danubian lowland, i.e., the center of the territory. The Little Carpathians form the northwest edge of the study area. The geomorphology of this area also conditions the properties of other landscape components and the occurrence of natural resources, which then influence the functional use of the area. High quality soils dominate among the natural resources and, in conjunction with favorable climatic conditions, create significant potential for agricultural development.

In the northern part of the district are rich forest resources. Some of the forests are exploited for timber production, and parts of the forests provide soil protection, mainly on steep slopes of Little Carpathians. Other protective forests are linked to hygienic protection of water sources. Most of the forest areas belong to the Little Carpathians Protected Landscape Area (PLA). The main economic base is industry and agriculture. Industrial production is concentrated in the city of Trnava. Industrial production is dominated by mechanical engineering, followed by food and textile industries. Production of electricity in the Trnava district is noticeable at a national level, due to the presence of the Jaslovské Bohunice nuclear power plant.

\section{Results}

Each landscape unit has diverse potential for fulfilling ecosystem services and for realization of individual socio-economic activities. The same landscape unit can provide the potential for a number of ecosystem services: biomass production and drinking water supply, as well as various non-productive functions, such as soil protection, biodiversity protection, etc. The utilization of many ecosystem services is often associated with negative impacts on the landscape and its components; e.g., the production of agricultural biomass is associated with intensive chemical use and mechanization, which is the cause of contamination and degradation not only of soil but also of water resources.

Our study area serves as an example for the assessment of environmental problems that are the result of conflicts between land use and nature protection, protection of natural resources and protection of the environment. The potential of ecosystems to provide services is not always used effectively. Productive ecosystem services are used more intensively (i.e., biomass for food production, drinking water, technical purposes etc., and, more recently, cultivation of crops for energy production), because their use is connected with direct economic gains, easily expressed by money (i.e., costs of agricultural production, water, wood, energy, etc.). This is reflected in the threat to non-productive and cultural ecosystem services. When using ecosystem services, the main focus is on one ecosystem service and the needs of other ecosystem services in the area are not always taken into account. This often results in conflicts in the use of ecosystem services and consequently in environmental problems. 
The use of some productive ecosystem services is linked to the production of undesirable polluting substances, i.e., stress factors that cause changes in ecological conditions of individual ecosystems (air pollution, soil contamination, vegetation damage, water contamination, noise and light pollution, etc.). Such altered environmental conditions limit the use of not only non-productive services, but also many productive services (soil contamination versus food production, loaded environment versus recreational activities, polluted water versus drinking water use, deterioration of environmental conditions versus biodiversity, etc.).

Transport of benefits from individual ecosystems to processors or end-users is also associated with negative impacts on surrounding ecosystems and thus makes it more difficult to use non-productive and productive ecosystem services. A typical negative example could be the threat to agri-ecosystems or cultural ecosystem services located near intensively loaded transport corridors (i.e., development of recreation due to negative transport impacts). The most busy transport corridors in the territory are: highway D61-Bratislava-Trnava-Piešt' any; first-class road I/51-Trnava-Sered', Trnava-Boleráz-Trstín; and, first-class road I/61-Cífer-Trnava-BučanyLeopoldov. The traffic intensity on these transport corridors reaches up to 50,000 vehicles per $24 \mathrm{~h}$ [65]. According to measurements, the equivalent noise level (LAeq) along the listed routes is $60-75 \mathrm{~dB}(\mathrm{~A})$, and the maximum noise level (LAmax) is in the range of $80-100 \mathrm{~dB}(\mathrm{~A})$, which is considered a significant noise load [66]. Such loaded areas are threats not only to biodiversity, but also restrict the development of socio-economic activities sensitive to hygienic environmental parameters, especially cultural and recreational services.

Although there have been positive trends in the production of emissions recently, there are still 184 large and medium sources of air pollution located in the territory of the Trnava district. In 2016, 92.23 metric tons of solid pollutants were released into the air; 144.37 tons of $\mathrm{SO}_{2} ; 270.84$ tons of $\mathrm{No}_{x}$; and, 118.33 tons of CO. Most of the sources are concentrated in the industrial center of Trnava. A few sources are also located in rural settlements-Boleráz, Smolenice and others. Areas with air pollution form concentrated elliptical zones in the outskirts of Trnava city.

These pollutants subsequently penetrate other components of the environment-soil, water, river sediments, etc. Increased concentrations of some foreign substances in the soil have been reported in the study area (cadmium, chromium, arsenic, magnesium and copper). Increased concentrations of cadmium in the soil were recorded in the range of $0.3-0.6 \mathrm{mg} \cdot \mathrm{kg}^{-1}$ in the southwestern part of the territory and in the Váh river alluvium. Across the region, higher chromium concentrations were recorded in the soil; these concentrations ranged from $85-101 \mathrm{mg} \cdot \mathrm{kg}^{-1}$, which is above allowed limits according to the Decree of the Ministry of Agriculture of the Slovak Republic no. 531/1994-540. Increased arsenic values occur both in the Little Carpathians, where they are of geogenic origin, but also in the lowlands where they are the result of intensive agricultural chemical use. Above-the-limit concentrations of manganese occur in the Little Carpathians, where they range from $0.14-0.41 \mathrm{mg} \cdot \mathrm{kg}^{-1}$. Increased content of copper is found in the study area in the wine-growing areas (i.e., the foothills of the Little Carpathians) [67].

Nitrates reach $62 \mathrm{mg} / \mathrm{L}$ in the Horné Orešany water resource. Elevated concentrations also occur in the central part of the region, which is the result of intensive agricultural production during the socialism period. The intensity of utilization of agricultural land significantly decreased after 1990 (after transition); a large number of hard accessible locations remained abandoned, there was a noticeable decrease in use of synthetic fertilizers, the intensity of mechanization decreased, etc. The consumption of synthetic fertilizers fell by almost half after transition, from $430 \mathrm{~kg} / \mathrm{ha}$ to $243 \mathrm{~kg} / \mathrm{ha}$ of agricultural land. Polluted water resources are a limiting factor for the development not only of non-productive services, but especially of productive ecosystem services. Polluted water is not suitable for drinking purposes. Water flows of the study area belong to the most polluted within Slovakia. Quantities exceeding limits of diatomic oxygen $\left(\mathrm{O}_{2}\right)$, biochemical oxygen demand, manganese, nitrogen and its forms, phosphates, total phosphorus, coliform bacteria and chlorophyll have been recorded in the main water flow of the Trnava district. Pollution is caused by discharging waste water from industry and urbanization. Agricultural production is also a major contributor to the pollution. A similarly 
unfavorable situation is also found on the Dolný Dudváh river, which shows quantities exceeding limits of phosphates, total phosphorus, coliform bacteria and chlorophyll.

The production of polluting substances also manifests in damage to the forest ecosystem. The most heavily loaded forest ecosystems are located in the northern part of the region, near Dobrá Voda municipality, where increased content of $\mathrm{Mg}$, Ni, $\mathrm{Se}, \mathrm{Sr}, \mathrm{Ca}, \mathrm{Cu}$ and $\mathrm{F}$ was recorded [68]. The loads of the area by stress factors is presented in Figure 4.

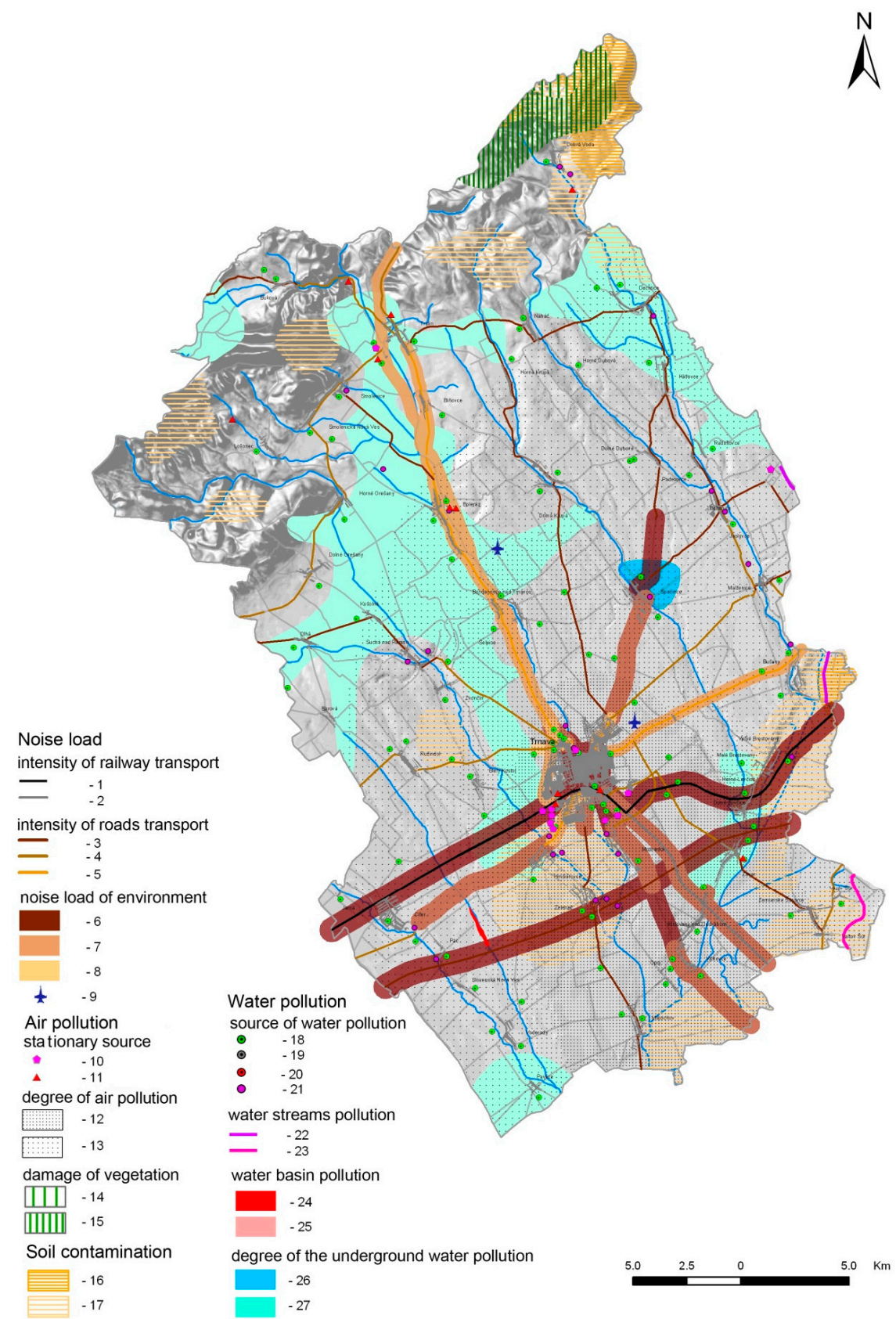

Figure 4. Anthropogenic stress factors (Noise load: 1-high, 2-medium, 3-very high, 4-high, 5-medium, 6-very high, 7-high, 8-medium, 9-airport; Air pollution: 10-large, 11-other important, 12-high, 13-medium, 14-high, 15-low; Soil contamination: 16-very high, 17-high; Water pollution: 18-from agriculture, 19-from industry and transport, 20-waste dump, 21—polluted water discharge site, 22-I. degree of pollution, 23-III. degree of pollution, 24-III. degree of pollution, 25-II. degree of pollution, 26-high, 27-medium). 
The contaminated landscape components act as stressors towards other landscape constituents and also restrict and limit the development of individual socio-economic activities.

Issues associated with conflicts in the use of individual ecosystem services and natural resources in the study area can be divided into categories as follows.

\subsection{Problems of Endangering of Ecological Stability of the Landscape}

These problems arise from the effects of stress factors on areas with a high eco-stabilizing effect, such as protected areas, forests, wetlands, green areas and below. The following conflicts can be included in this group:

(a) Endangering the spatial ecological stability of the landscape and endangering of the biodiversity by intensive agricultural production

Individual natural ecosystems have been gradually taken up, disposed of and replaced by agri-ecosystems due to the development of intensive agriculture [69]. This has led to the gradual transformation of the Trnava region area into a monofunctional intensely utilized agricultural landscape with a low degree of ecological stability. The current landscape structure is dominated by arable land, which occupies $61 \%$ of the total area of the region. Intensive agricultural production (intensive chemical use and mechanization) is a significant stress factor in terms of biodiversity. The assessment of the ecological stability of the study area was carried out on the basis of the change of natural representative geo-ecosystems (REPGES). REPGES are landscape units based on abiotic complexes and potential vegetation. Altogether 96 REPGES were allocated in the area of the region [70]. The assessment of the preservation/anthropogenic change of REPGES was performed on the basis of the coefficient of naturalness [71], which expresses the actual percentage of natural vegetation within the different types of REPGES. Up to $17.7 \%$ of the REPGES types do not have any natural vegetation and up to $27 \%$ of REPGES have no natural vegetation percentage greater than $1 \%$. $30 \%$ of REPGES types have a $50 \%$ representation of natural vegetation; these are REPGES located in the northern part of the region within the Little Carpathian PLA. The structure of the REPGES types based on the coefficient of naturalness is expressed in Figure 5.

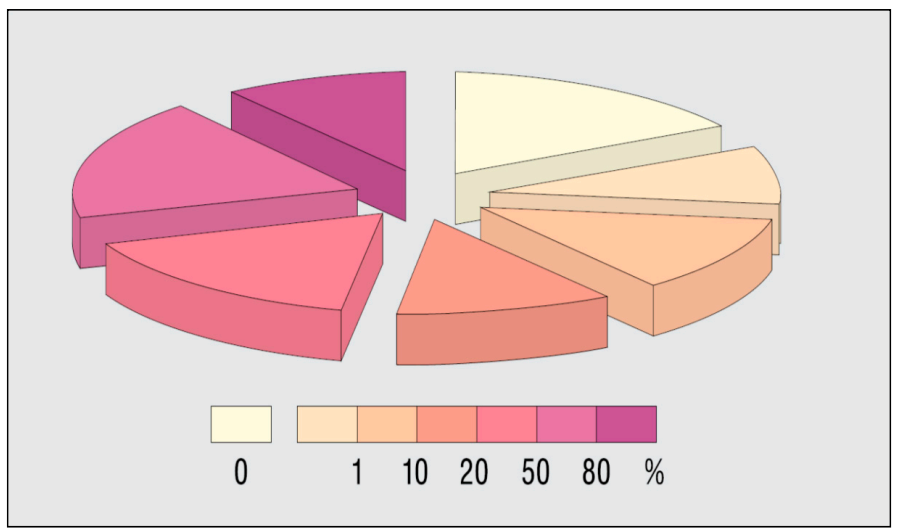

Figure 5. Percentage representation of natural ecosystems within individual representative geo-ecosystems (REPGES)/coefficient of naturalness.

(b) Endangering the spatial ecological stability of the landscape by the elimination of landscape greenery

Numerous harvests of natural linear habitats have been recorded in the area, and these habitats were then replaced by robinia and poplar artificial monocultures. As a result of the intensification of agricultural land, many boundaries, windbreaks and last remnants of linear vegetation, which prevented the use of heavy machinery, have been eliminated. Many of these have been replaced 
by artificial, non-original ecosystems. After the transformation (after 1989), agricultural production has declined and many agricultural parcels, mainly those that are isolated, have been abandoned. Many areas are currently transforming into built-up areas in the lowlands, and into forests in the foothills. The development of the share of agricultural land, forests and built-up areas is shown in Figure 6. The proportion of vegetation within the boundaries of cities and towns has decreased [72]. The share of public vegetation per capita in the region is $29.9 \mathrm{~m}^{2}$, which is below the Slovak average (34 $\mathrm{m}^{2}$ per inhabitant).

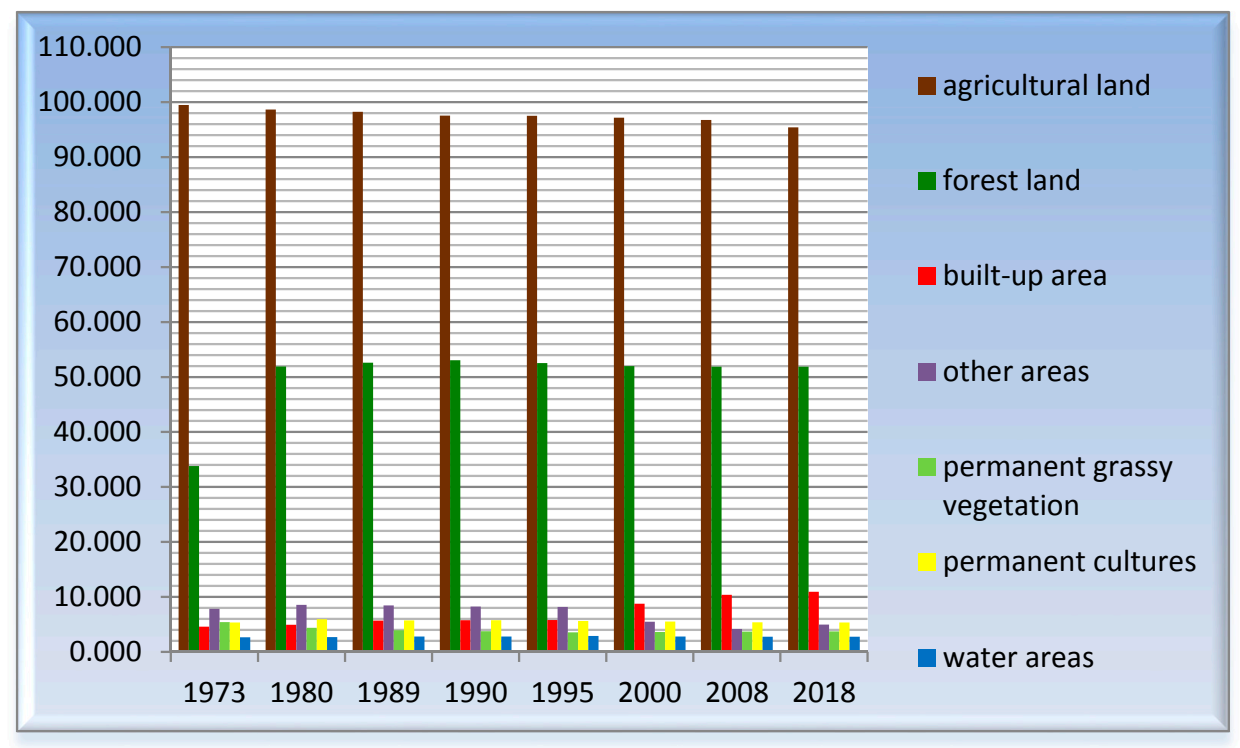

Figure 6. Development of land use in Trnava district (ha).

(c) Endangering of human environment by the intensive agriculture and spreading of ruderal vegetation

Agrocenoses brought and spread non-original plant species, mainly weeds from the Secalietea class. Species such as Consolida regalis, Tithymalus exiguus, Tithymalus falcatus, Mercurialis annua, Lathyrus tuberosus, Stachys annua, Mercurialis annua, Convolvulus arvensis and others are common in this area. This vegetation occurs in man-affected sites or artificial habitats. The largest expansion of this vegetation has been recorded in intravilan, but it is also often found in extravilan, especially next to field trails, agricultural objects and dumps. Many species also penetrate into relatively natural habitats. Among the species most commonly found in ruderal habitats are: Urtica dioica, Ballota nigra, Agropyron repens, Cirsium arvense, Lactuca serriola, Convolvulus arvensis, Conium maculatum, Falcaria vulgaris, Artemisia vulgaris, Amaranthus retroflexus, Chenopodium spec. div., Atriplex spec. div., Arctium lappa, Panicum miliaceum, Cannabis ruderalis, Aster novi-belgii agg., Conyza canadensis and others. These species also reduce the aesthetic value of the environment. Among the invasive species can be found Robinia pseudoacacia, Negundo aceroides, Lycium barbarum, Ailanthus altissima, Conyza canadensis, and Fallopia japonica [73].

(d) Endangering of the biodiversity by timber production

This is a threat to protected areas and elements of the territorial system of ecological stability (TSES) due to intensive wood harvesting, including in Vlčkovský háj protected area, Buková nature reserve, Kamenec biocentre, Šarkan, Farský Mlyn and Holý vrch biocentres, and Podmalokarpatský and Parná bio-corridors. The problem is also wood harvesting in the Little Carpathians PLA, which has a main function of biodiversity protection. The area of the economic forests in the region is $70 \%$ of the total forest size, which determines their exploitation for wood production. The problem is that up 
to $90 \%$ of forests are located in the Little Carpathians PLA and its protection zone, where there are conflicts of interest between nature conservation and forest owners and users. Wood harvesting is about 50,000 $\mathrm{m}^{3}$ per year; in 2015 it was $58,376 \mathrm{~m}^{3}$ and in 2017 it was $53,563 \mathrm{~m}^{3}$.

(e) Endangering of the biodiversity by water resources exploitation

Excessive water consumption and unnecessary waste of water leads to a reduction in surface and ground waters, resulting in a change in the ecological conditions of many ecosystems, especially wetlands. Climate change also contributes to decreasing water flow rates. Water depth in the Trnávka stream in the mountains reaches an average value of $105 \mathrm{~cm}$; in the lowlands its depth is only $17 \mathrm{~cm}$. In particular, floodplain forests in the vicinity of the region's water flows are threatened as a result of an uncontrollable water supply for irrigation of gardens, especially during dry seasons in summer. Although water consumption after the transformation has decreased, it can still be considered high. In 2015, specific water consumption was 165 liters per inhabitant per day [74]. Unmanageable use directly from watercourses or from private wells, which contribute to a drop in surface or groundwater, are particularly dangerous.

(f) Conflicts between nature conservation and recreational resources

Relationships between non-productive and cultural-recreational services are reciprocal. On one hand, the intensive and inefficient use of cultural-recreational services is a threat to nature and biodiversity protection; on the other hand, the protection zones and protected areas declared to protect non-production ecosystem services are limitations and constraints for the use of cultural ecosystem services. The intensive and uncontrollable development of recreation is a negative factor in terms of biodiversity protection and protection of the nature and landscape of the Trnava region. Plant ecosystems are endangered by trampling, plucking rare plants, storing waste, etc. For fauna, the main stress factors are noise, disturbance, destruction of nesting sites and poaching [75]. IN particular, areas of the Little Carpathians Protected Landscape Area (PLA) and the Trnavské rybníky Protected Area (PA) are threatened by recreation. Trnava ponds PA is negatively impacted by intensive fish farming and sport fishing, as well as by increasing tourism and expanding construction in the surroundings. Recently, individual housing construction has occurred significantly closer to the boundaries of this protected area. The Little Carpathians PLA is threatened due to uncontrolled cottage construction. An additional problem is also the storage of waste in protected areas and the creation of unorganized waste dumps.

\subsection{Problems of Endangering the Natural Resources}

These arise due to the effect of stress factors on individual natural resources. The result is a qualitative and quantitative threat to individual natural resources.

(a) Endangering the soil resources by industrialization and urbanization

Socio-economic development in the region is accompanied by pressures on agro-ecosystems, often with the highest quality soils. Up to $70 \%$ of agriculture soil fund belong to the fourth-best categories within Slovakia [76]. After the changes doe to transformation in 1990, the region has undergone intensive socio-economic development characterized by significant spatial impacts. Construction of industrial and logistic facilities, transport networks, shopping centers and residential areas takes up the largest areas of soil. Construction works often utilize best quality soil. An example of such a negative impact on agri-ecosystems is the construction of PSA Peugeot Citroën Slovakia and several electrotechnical plants, of which Samsung Voderady could be considered as the most dominant. While these units have contributed to improving socio-economic conditions of the region, their development is also associated with negative impacts, especially in the environmental field. New industrial plants have been built, often on "green meadows", and are causing significant pressures on natural and semi-natural ecosystems and on natural resources. PSA Peugeot Citroën Slovakia was built on 192 ha of quality soils (the best quality in Slovakia). 
The decline of arable land is an environmentally negative phenomenon, especially in relation to removing arable land from the agricultural land fund and re-allocating it to the built-up area [77].

At the same time, the closure and liquidation of agricultural cooperatives and industrial plants has caused an increase in abandoned buildings and ruins. After Bratislava, Trnava is one of the regions with the greatest increase in built-up areas in Slovakia [78], as new industrial and commercial activities are located on regional and trans-regional axes, as well as in the city center. New technical buildings have also been constructed in rural settlements, where atypical garden suburbs are created. A similar situation exists in other European countries. Agricultural land is reduced. In the EU during the past 15 years, about $6.5 \%$ (12.5 million ha) was occupied. Daily surface sealing in Germany is approx. 71 ha, and in the Czech Republic approx. 25 ha [79]. This construction is linked not only with a whole range of environmental issues, but also with social problems. Immigrant populations are often difficult to assimilate into the settlement community, and new elements are emerging in settlement communities-isolation, closeness, separation, constraint of communication, egoism, preference of own local interests, loss of interest in public affairs, etc., which is reflected in a change of lifestyle and consequently in the quality of community life. New psychosocial phenomena such as divorce, unrestrained lifestyles, crime, drugs, etc., are beginning to permeate [80]. "Consumer egoism" can also be seen in the increase in the built-up area size per capita (Figure 7) [1].

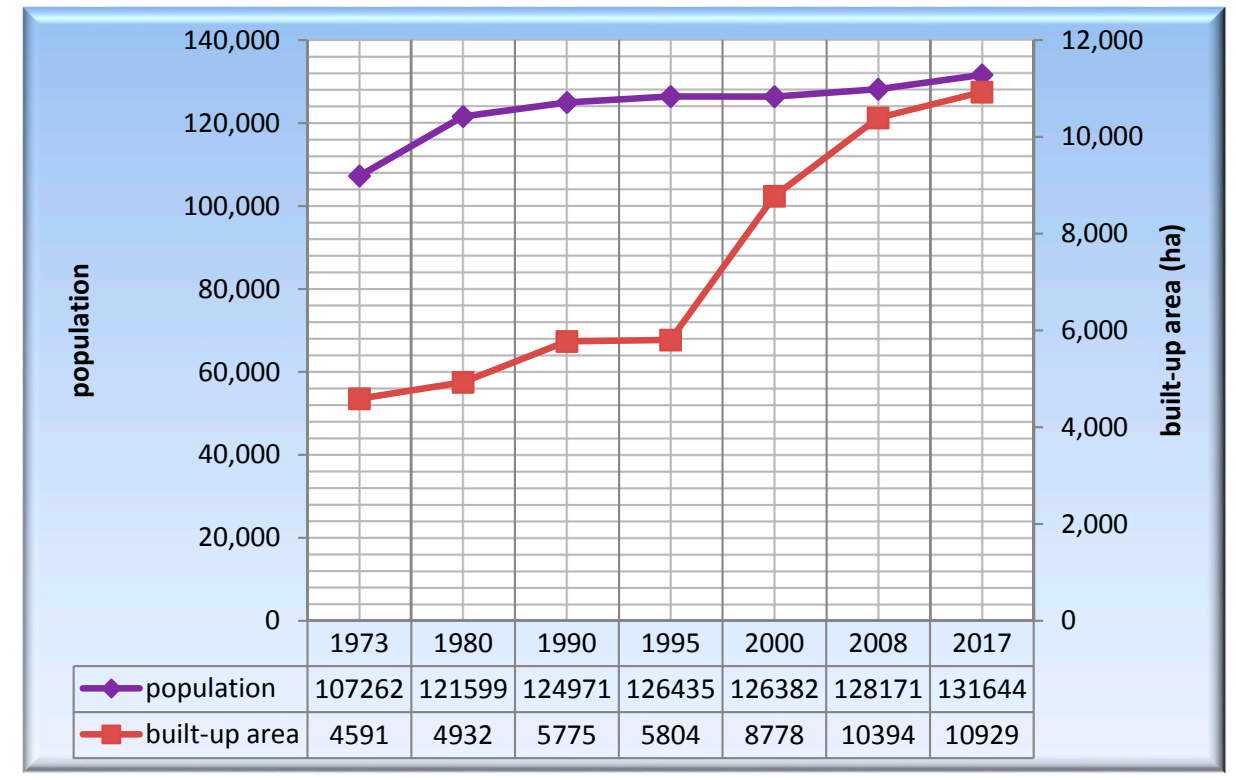

Figure 7. Built-up area vs. population in Trnava district.

(b) Endangering the soil resources by intensive agriculture

Inappropriate management of the soil by its owners and users of the land in biomass production causes physical degradation of the soil, especially by the effects of hard packed soil and erosion processes. Such disturbed soil weakens non-productive functions, such as soil biodiversity protection, soil quality protection, etc. Degraded soil also reduces biomass production. In the Trnava district, up to $80 \%$ of ASF are at risk due to hard packed soil, of which up to $65 \%$ are at risk due to inappropriate management of the soil [76]. Approximately $30 \%$ of ASF are threatened by wind erosion, of which $7.9 \%$ are in the category of severe erosion and $1 \%$ in the category of extremely endangered soils by wind erosion. Wind erosion causes secondary dustiness in settlements lying in the lowlands of the region. About $30 \%$ of ASF are threatened by water erosion, of which heavy erosion occurs on $18 \%$ of ASF and $2.5 \%$ of ASF are in the category of extreme erosion with soil transport (40 t/ha/year) [76]. Flat windy parts of the Trnava plain are at risk in terms of spatial wind erosion, while water erosion dominates in the mountainous areas of the Little Carpathians. 
(c) Conflicts between nature conservation, water protection and use of soil resources

Protected zones and areas associated with the protection and use of many non-productive functions restrict and limit intensive development of agricultural production and wood harvesting and thus make it more difficult to use agri-ecosystems and forest ecosystems for biomass and wood production (e.g., protected areas and their protected zones, zones of hygienic protection of water sources, etc., are limitations for the wood harvesting development). Regarding the protection of waters by the Nitrates Directive (91/676/EC), 44.3\% of the territory was classified as land with a middle-class constraint for land management and $0.05 \%$ is in the category with the highest level of farming constraint on the land [76]. Protected and special purpose forests constitute 13\% and 17\%, respectively, which acts as a limit for forestry development. Protected areas and various protected zones, mostly kept for the protection of non-productive functions, are limiting the development of cultural and recreational services and the development of recreational activities, similar to the case for productive services.

\subsection{Problems of the Endangering of Human Environment}

These problems arise from the effects of stress factors on the human environment-the effect of stress factors on residential and recreation areas. The following issues can be included in this category.

(a) Conflicts between development of socio-economic activities and the environment

As we have already mentioned above, the realization of many socio-economic activities is associated with the production of polluting substances which contaminate the individual components of the environment, and which subsequently results in deterioration of the quality of the environment. Impaired environmental quality includes that of the Trnava city center, where several sources of air and noise pollution are located. There are also threatened settlements lying around Trnava (see Figure 4). Inappropriate localization of production facilities, as well as abandonment of rubbish, is reflected in the reduced aesthetic value of individual settlements.

(b) Conflicts between agriculture and recreational resources

Areas with a loaded environment are not suitable for the development of recreation and tourism in terms of hygienic conditions. Similarly, an agricultural landscape with a low degree of ecological stability that is used intensively and one-sidedly is not attractive for recreation and tourism development. There is no developed tourism in the entire central part of the Trnava region, which is extensively farmed. Tourism is concentrated only in parts of the Little Carpathians PLA, where it is in conflict with nature conservation. In agricultural areas, tourism is concentrated in water reservoirs-Suchá nad Parnou, Boleráz, Buková. Boleráz and Suchá nad Parnou water reservoirs were originally built for agricultural irrigation, but currently are used mainly for water regulation in the country and for sport purposes. In particular, sport fishing is popular there. Swimming is limited due to poor water quality, because the content of coliform bacteria, faecal streptococci, phenols, nonpolar extracts and cyanobacteria is excessive. These increased indicators point to an increased degree of eutrophication caused by agricultural activity and, in particular, by municipal pollution [81].

(c) Conflicts between forestry and recreational resources

Wood harvesting is also associated with negative environmental impacts, such as degradation of forest ecosystems, increased noise and dustiness, etc. These factors represent the main stressors and limits of the development of cultural and recreational activities. This conflict is typical for the Little Carpathians PLA. The degree of limitation depends on the nature of the protected zone and the degree of protection. With an increasing degree of protection, the degree of limitation for the development of individual recreational activities is also increasing [82]. 


\subsection{Integrated Assessment of the Conflicts of Interests in Trnava District}

The map in Figure 8 presents the integration of all spatial encounters of the interests of all sectors described above.

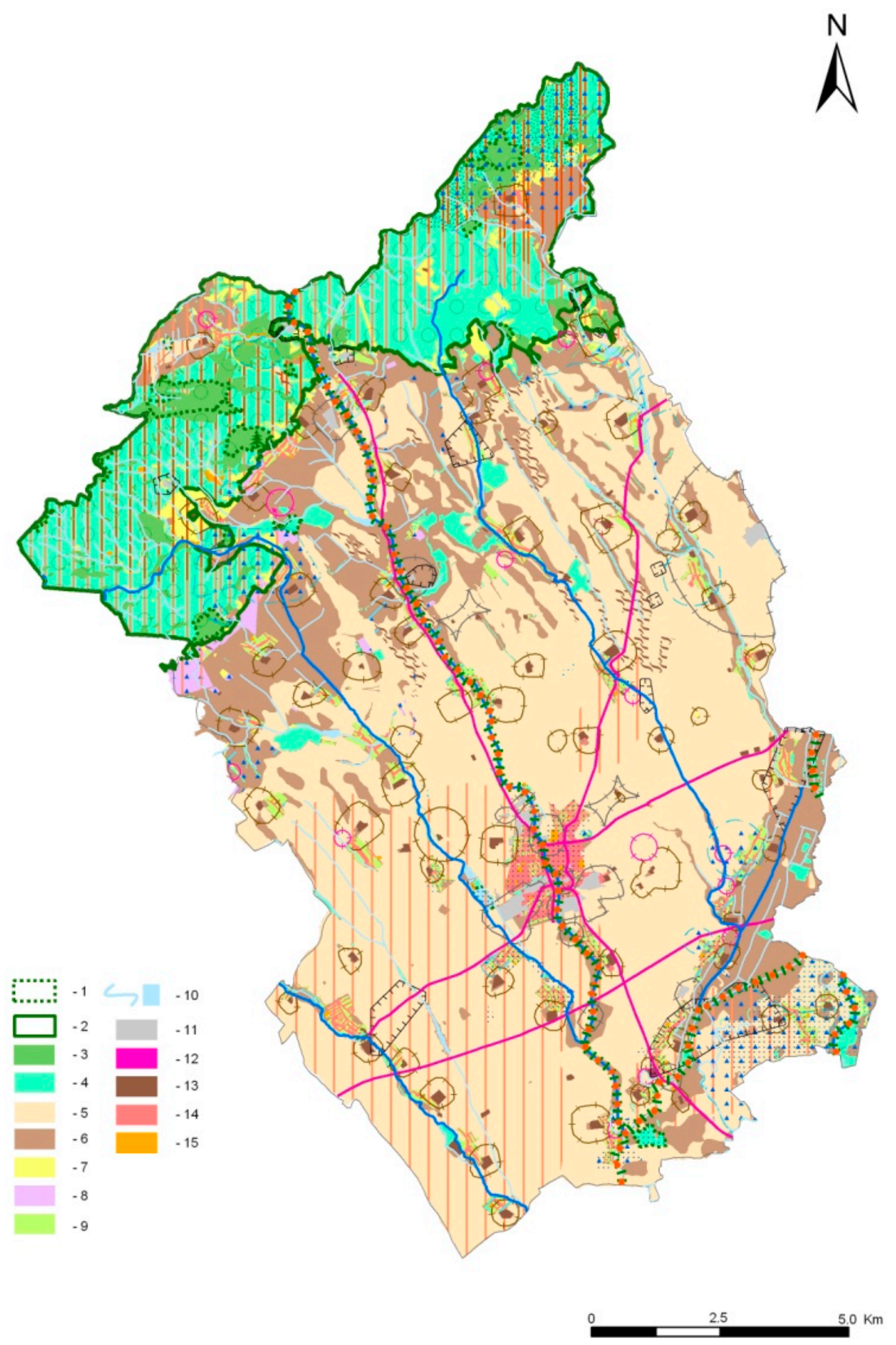

(a)

Figure 8. Cont. 


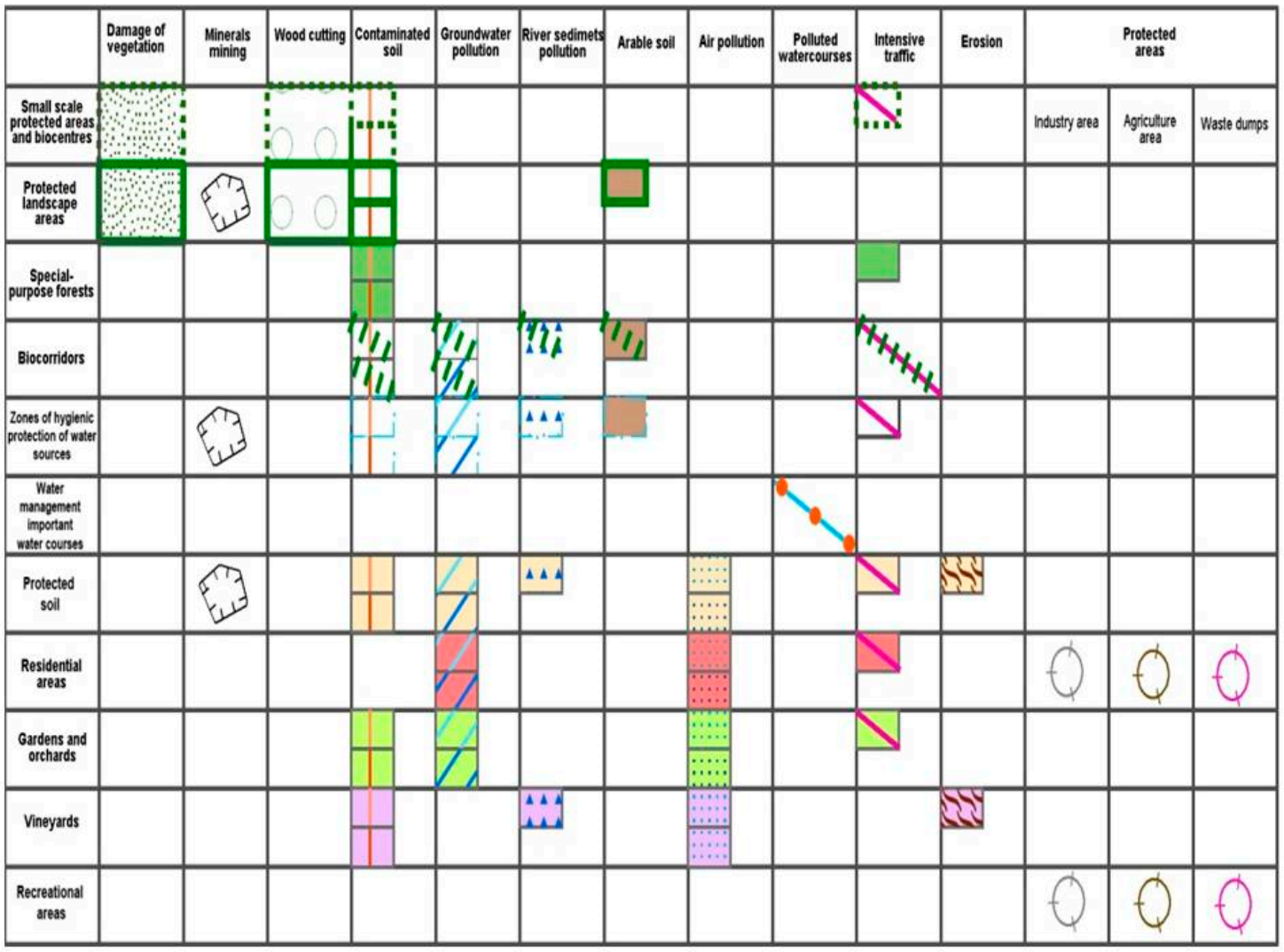

(b)

Figure 8. Conflicts of interests in the landscape-environmental problems: (a) The input characteristics. 1-Small scale protected area, 2-Protected landscape area Malé Karpaty, 3-Special-purpose forests, 4-Productive and other forests and non-forest woody vegetation, 5-Protected soils, 6-Other types of soils, 7-Permanent grassy vegetation, 8-Vineyards, 9-Gardens and orchards, 10-Watercourses and all surface water, 11-Industrial areas, 12-Waste dump, 13-Agricultural areas, 14-Residential areas, 15-Recreational areas; (b) Matrix of conflicts of interests in the landscape-environmental problems. Rows represent environmentally positive factors; columns represent environmentally negative factors; squares represent real existing encounters of positive and negative factors in the model territory.

The input data are the relevant elements of all three structures of geosystems-PLS, SLS and TLS-which occur in the Trnava district.

The decisive elements of the primary landscape structure (PLS) in the district are soils of high quality ranked to 2 classes (keys 5 and 6 in the legend to Figure 8), and the water courses and other surface waters (key 10).

The decisive elements of the secondary landscape structure (SLS) are forests and other woody vegetation in the landscape (keys 3 and 4), arable land (keys 5 and 6), grasslands (key 7), vineyards (key 8), gardens and orchards (key 9), industrial areas (key 11), waste dumps (key 12), agricultural objects and areas (key 13), and residential areas (key 14).

The decisive elements of the tertiary landscape structure (TLS) in the district are bounded to nature conservation (key 1 and 2), to protection of forest resources (key 3) and soil resources (key 5).

It is obvious that these elements are mutually interrelated and they partially overlap each other. For example:

- $\quad$ The high quality and other productive soils are used as arable land (key 5 and 6). Moreover, the highest quality soils were declared for protected soils.

- The nature conservation areas are declared for forests; thus, these forests were declared as special-purpose forests (key 1, 2,3 and 4). 
- $\quad$ The industrial areas, agricultural objects, waste dumps are bound with their safety and hygienic zones, etc.

In addition to these permanent elements, the map also shows the spatial distribution of the contamination by industry.

The spatial projection of the factors described above allows the assessment of their spatial encounters from the ecological/environmental point of view as characterized in Section 3:

- $\quad$ rows represent environmentally positive factors that are endangered by negative factors;

- columns represent environmentally negative factors that endanger the positive factors;

- squares represent the real existing encounters of positive and negative factors in the model territory.

The analysis and characteristics of the encounters and conflicts is the base for finding solutions for their mitigation.

\section{Discussion}

As shown with the example of the model area, the environmental problems issuing from non-harmonized approaches to land use cause real environmental problems. Environmental issues related to landscape changes and the need for solutions have been highlighted by the European Environmental Agency (EEA) and many other authors who point to the continuing threatening of natural ecosystems, either direct or by changing their ecological conditions [83-93].

The encounter of interests of sectors in the model territory appear basically in 4 modes:

(a) The sectors "fight" for land to broaden their own territory. This is expressed in the building of new objects for industry, transport and residential areas. An important specific problem of the district is that most of its soils are of the highest quality and productivity, so are protected. Nevertheless, developers are able to find ways to change existing territorial plans and gain land, even if they must pay compensation for the occupied land. The problem of occupation of the best soils for industry, shopping centers and residential complexes has been the topic of much research [94-97]. Another specific problem is the motorway, which creates a massive barrier against migration of the biota. This issue is to be addressed according to the result of the project of the Regional Territorial System of Ecological Stability of the district [98].

(b) The sectors of forestry, agriculture, water management, nature conservation and recreation utilize large areas where their activities overlap. Characteristic of this group is the spatial overlap of the Protected Landscape Area Small Carpathians with special purpose and protective forest and water protective zones, which are mutually supportive. The opposite case is the spatial overlap of high quality soils in the water protective zones, which has a characteristic of conflict since the use of agrichemicals in order to exhaust the productivity potential endangers and pollutes water resources. This conflict should be mitigated by respecting the legal limitations for agriculture. Nevertheless, as the monitored data show, the pollution of water resources still occurs.

(c) "Internal" conflicts within the sectors, i.e., conflict of the activity with its own land resources. This is a typical problem of Trnava district. Intensive agriculture on arable land on steep slopes and on shallow soils causes erosion. This problem is to be solved urgently by acceptance of projects for land consolidation, which also include a proposal for a local territorial system of ecological stability; this is, in fact, a detailed proposal for landscape greenery, which provides complex eco-stabilizing functions, including protection against erosion [99-101].

(d) Production of pollution: most typical are air pollution, which influences the residential and recreational areas, and water pollution, which endangers the water quality both of surface and underground water. A very specific feature of the district is the presence of the nuclear power plant, Jaslovské Bohunice. According to the Environmental Regionalization of the Slovak Republic, the territory of the district of Trnava belongs to the most environmentally burdened regions of Slovakia [77]. 


\section{Some Characteristic Issues Concerning the Model Territory}

The most important driving forces in the area of interest were the period of socialization and collectivization, and the process of transformation. The collectivization period (1950s-1960s) was characterized by the establishment of cooperatives. Thus, the process of concentration and consolidation of estates began, and the creation of a monofunctional agricultural landscape started. This led to the disappearance of many valuable representative ecosystem types. A similar process was also recorded in forestry. Intensive wood harvesting took place and inappropriate forms of forest management began, which subsequently threatened the natural character and species composition of forest ecosystems. Typical for this period was also the thoughtless removal of orchards, gardens and small-blocked vineyards, thus eliminating traditional gardening and fruit growing. Similarly, the last remaining ecosystems were removed, and the whole area of lowlands was transformed into monotone, intensively used arable land with a low degree of ecological stability [102].

The period after 1989 is characterized by the reduction of central planning and the transition to a market economy. During this period, strong pressure from investors to build new industrial facilities and residential areas is typical. This is exemplified by automotive and technology parks, logistics centers and transport infrastructure. The region has become one of the most industrialized areas in Slovakia. This investment is quantitatively reflected in sequestration of natural resources and semi-natural ecosystems, and qualitatively by threatening both environmental quality and natural resources. The growth in built-up areas has altered natural and semi-natural ecosystems and changed agricultural and forest-based land use. The accompanying loss of arable land, planting of forests with increased unused agricultural areas, and the elimination of vineyard and fruit orchard crops have changed the landscape of the model territory [78,103,104].

Similar development was also observed in regions in other post-communist countries (Czech Republic, Poland, Hungary and Bulgaria), where original activities were replaced by new ones. These took the form of commercialization [105,106], construction of new apartments [107], brownfield regeneration $[108,109]$ and the establishment of new commercial centers $[110,111]$. The emergence of brownfields and decline of some housing estates constructed during socialism highlighted major problems remaining in post-socialist cities [112].

The basic tool for eliminating these problems in the landscape is the application of integrated landscape management aimed at the ecologically optimum spatial organization, utilization and protection of the landscape, which results in a proposal for the most suitable localization of demanded human activities within the given territory (what and where?) and successively to the proposal of necessary measurements ensuring the ecologically proper functioning of those activities on the given locality (how?). The European Union has shown a strong effort towards the application of integrative tools towards the optimum utilization of natural resources. In particular the Integrated Pollution Prevention and Control (IPPC) Directive, the Network of nature protection areas (NATURA 2000), and the Water Framework Directive should be mentioned in this respect. These are intended to be supported by the Infrastructure for Spatial Information in the European Community (INSPIRE). Directive, which enforces the integrated spatial information system as the inevitable basis of an integrated approach. The Water Framework Directive defines integrated river basin management $a$ s the process of coordinating conservation, management and development of water, land and related resources across sectors within a given river basin. Other concepts of integrative character include the Europäische Raumordnungs Charta, the Alpine Convention, the Carpathian Convention, the Danube River Protection Convention and the European Landscape Convention of the EEC, and, naturally, also the EUSDR and other regional strategies.

\section{Conclusions}

As characterized in the paper, the encounters, conflicts and environmental problems show significant diversity, which underlines the need for integrated solutions. The presented assessment procedure resulted in the identification and analysis of the conflicts of interests in the territory and 
their projection to a map. However, this is only the first step in the solution of problems, and should be followed by implementation of procedures for ecologically optimum spatial organization and utilization of the territory in regular spatial planning processes.

Land use changes are also the main root of many environmental problems [113-115]. This is the consequence of the sectoral approach to land use. Therefore, the assessment of land use changes should be followed by the evaluation of their environmental impacts. This evaluation requires new methods that consider not only the complexity of socio-economic dynamics, but also interdependencies between drivers, impacts, and responses to these dynamics [116].

In line with the basic provisions of AGENDA 21 and newer environmental-political documents enhancing the integrative approaches, we consider land-use planning the main tool for influencing sectoral activities in an early stage of planning and, thus, as the tool for harmonization of sectoral approaches. Local government should respond to all current challenges of spatial development, trends and environmental issues [73,117-120].

Slovakia has well-developed landscape-ecological planning [1]. The application of landscape documents (landscape plans and ecological networks) to spatial planning processes is legally anchored. However, in practice, landscape-ecological principles are difficult to integrate into spatial planning documentation for a range of different reasons. In conclusion, these include the significant pressures of investors and landowners to invest on "green meadows", which leads to the occupation of natural areas. The owners are no longer interested in the management of small lots of land or have no technical, financial or human options for management, and thus their aim is to evaluate properties by realizing investment plans. Similar situations occur in other post-communist countries [105,121-124]. In Slovakia, Poland, the Czech Republic, and Hungary the process of shaping the structure of land ownership started anew after 1990, with dynamic changes taking place in land use [123-126]. This was especially visible in metropolitan areas, where competition for land was the highest, and the development of private sector enterprises and growing urbanization resulted from conversion of agricultural land [125-127].

One other problem is the low environmental awareness of local authorities who approve development projects. Investment objectives and growing urbanization were priorities in most municipalities, while ecological interests and priorities are at the edge of residential development goals [128-131].

Therefore, in spite of professional and legal support, the actual implementation of comprehensive physical planning (in different countries referred to as land-use planning, spatial planning, landscape planning, etc.) - which should provide a complex framework for harmonization of the activities of all sectors-is in practice inadequate and needs significant strengthening. The sectoral approach is still prevailing, and the developer's plans are aimed firstly at localization and realization of industrial, transport, business and housing activities without adequate consideration of other sectors, such as agriculture and nature protection. These problems occur all around the word as the consequence of global megatrends.

The theoretical, methodical and legal conditions to approximate the integrated approach and harmonization of land use in order to avoid conflicts of interests of sectors causing environmental problems are given here. The problem remaining to be solved is the strengthening of their application into planning practice and realization.

Author Contributions: Z.I. contributed to the creation of the theoretical context of work and also wrote the majority of the discussion and conclusion. She processed the assessment of environmental problems on study area. L.M. compiled the methodology and theoretical context of work and also contributed to create a discussion and conclusion. V.M. participated in the evaluation of interest encounters in the study area and processed graphical attachments and maps in the GIS.

Funding: This research was funded by grant agency VEGA-Ministry of Education SR and Slovak Academy of Sciences (No. 2/0066/15 Green Infrastructure of Slovakia and No. 1/0096/16: Ecosystem services of the landscape ecological complexes in the area of the UNESCO World Cultural and Natural Heritage site Banská Štiavnica and surrounding technical monuments). 
Acknowledgments: This research was funded by grant agency VEGA-Ministry of Education SR and Slovak Academy of Sciences (No. 2/0066/15 Green Infrastructure of Slovakia and No. 1/0096/16: Ecosystem services of the landscape ecological complexes in the area of the UNESCO World Cultural and Natural Heritage site Banská Štiavnica and surrounding technical monuments).

Conflicts of Interest: The authors declare no conflict of interest.

\section{References}

1. Izakovičová, Z.; Mederly, P.; Petrovič, F. Long-term land use changes driven by urbanisation and their environmental effects (example of Trnava City, Slovakia). Sustainability 2017, 9, 553. [CrossRef]

2. Munteanu, C.; Kuemmerle, T.; Boltiziar, M.; Butsic, V.; Gimmi, U.; Kaim, D.; Király, G.; Konkoly-Gyuró, É.; Kozak, J.; Lieskovský, J.; et al. Forest and agricultural land change in the Carpathian region-Ameta-analysis of long-term patterns and drivers of changes. Land Use Policy 2014, 38, 685-697. [CrossRef]

3. Lieskovský, J.; Burgi, M. Persistence in cultural landscapes: A pan-European analysis. Reg. Environ. Chang. 2018, 18, 175-187. [CrossRef]

4. EEA. The European Environment State and Outlook 2015. Assessment of Global Megatrends; European Environmental Agency Copenhagen: København, Denmark, 2015; p. 134.

5. FAO. The State of the World's Forests 2018-Forest Pathways to Sustainable Development; Licence: Rome, Italy, 2018.

6. Mitchley, J.; Tzanopoulos, J.; Cooper, T. Reconciling conservation of biodiversity with declining agricultural use in the mountains of Europe. In Interdisciplinary Research and Management in Mountain Areas; Taylor, L., Ryall, A., Eds.; Banff Centre Canada: Banff, AB, Canada, 2005; pp. 61-65.

7. The EU Biodiversity Strategy to 2020. Available online: http://ec.europa.eu/environment/nature/ biodiversity/strategy/index_en.htm (accessed on 10 September 2018).

8. Grunewald, K.; Bastian, O. (Eds.) Ecosystem Services. Concept, Methods and Case Studies; Springer: Berlin, Germany, 2015; p. 312.

9. Fürst, C.; Helming, K.; Lorz, C.; Müller, F.; Verburg, P. Integrated land use and regional resource management-A cross-disciplinary dialogue on future perspectives for a sustainable development of regional resources. J. Environ. Manag. 2013, 127, 1-5. [CrossRef] [PubMed]

10. Krcho, J. Structure and spatial differentiation of the physical-geographic sphere as a cybernetic system. Bratislava. Geogr. Čas. 1974, 26, 132-162.

11. Haase, G. Izučenie topičeskich I choričeskich struktur, ich dinamiki I razvitija v landšaftnych sistemach. In Structura, Dinamika I Razvitije Landšaftov; Institut Geografii. AN SSSR: Moskva, Russia, 1980; pp. 57-81.

12. Miklós, L.; Izakovičová, Z. Landscape as Geosystem; VEDA, SAV: Bratislava, Slovakia, 1997; p. 152.

13. Miklós, L.; Izakovičová, Z.; Boltižiar, M.; Diviakova, A.; Grotkovská, L.; Hrnčiarová, T.; Imrichová, Z.; Kočická, E.; Kočický, D.; Kenderessy, O.; et al. Atlas of Representative Geosystem of Slovakia; UKE SAV: Bratislava, Slovakia, 2016; p. 123, ISBN 80-969272-4-8.

14. Ružička, M.; Miklós, L. Landscape-ecological Planning (LANDEP) in the Process of Territorial Planning. Ecol. CSSR Cas. Ekologicke Probl. 1982, 1, 297-312.

15. Miklós, L. Ecological Generel, ČSSR Part: SSR. I. Stage. Spatial Differentiation of the Area from the Ecological Point of View; ČSŽP Bratislava, ÚEBE CBEV SAV Bratislava, Stavoprojekt: Banská Bystrica, Slovakia, 1985; p. 125.

16. Miklós, L.; Kozová, M.; Ružička, M. Ecological Plan for the Use of the East Slovak Lowland at 1:25,000. Ecological Optimization of Use of VSN; ÚEBE SAV: Bratislava, Slovakia, 1986; pp. 5-312.

17. Izakovičová, Z. Ecological interpretations and evaluation of encounters of interests in landscape. Ekológia 1995, 14, 261-275.

18. Izakovičová, Z. Evaluation of the stress factors in the landscape. Ekológia 2000, 19, 92-103.

19. Izakovičová, Z. Integrated approach to the assessment of the agricultural landscape. Geogr. Rev. Geogr. Geoekologické Štúd. 2006, 2, 333-339.

20. Izakovičová, Z. Integrated Landscape Management; Institute of Landscape Ecology, SAS: Bratislava, Slovakia, 2006; p. 232.

21. Miklós, L.; Diviaková, A.; Izakovičová, Z. Ecological Networks and Territorial System of Ecological Stability; Springer International Publishing: Berlin, Germany, 2018; p. 159. 
22. Krcho, J. The natural part of the geosphere as a cybernetic system and its expression in the map. Geogr. Čas. 1968, 20, 115-130.

23. Chorley, R.; Kennedy, B. Physical Geography-A System Approach; Prentice Hall Interantional: London, UK, 1971; p. 243.

24. Demek, J. The landscape as a geosystem. Geoforum 1978, 9, 29-34. [CrossRef]

25. Sochava, V.B. Vvedenie v Učenije o Geosistemach (An Introduction to the Science of Geosystems); Nauka: Novosibirsk, Russia, 1978; p. 319.

26. Miklós, L.; Kočická, E.; Izakovičová, Z.; Kočický, D.; Špinerová, A.; Diviaková, A.; Miklósová, V. Landscape as a Geosystem; Springer International Publishing: Berlin, Germany, 2018; p. 245.

27. Izakovičová, Z.; Miklós, L. New concept of nature protection in the Slovak Republic. In Nature Conservation Management: From Idea to Practical Results; Chmielewski, T.J., Ed.; PWZN Print 6; Lublin-Lódz-Helsinki: Aarhus, Denmark, 2007; pp. 86-98, ISBN 83-87414-98-0.

28. Miklós, L.; Špinerová, A. Landscape-Ecological Planning LANDE; Springer: Berlin, Germany, 2018; p. 254.

29. Izakovičová, Z.; Miklós, L.; Drdoš, J. Landscape-Ecological Conditions of Sustainable Development; Veda: Bratislava, Slovakia, 1997; p. 183, ISBN 80-224-0485-3.

30. Kočická, E. Príklad Ohraničovania Komplexných Priestorových Jednotiek pre Krajinno-Ekologické Hodnotenia. Acta Facultatis Ecologiae 2011, 24-25, 55-65. Available online: https://fee.tuzvo.sk/sites/ default/files / acta-fee-24-25-2011.pdf (accessed on 12 September 2018).

31. Miklós, L.; Izakovičová, Z.; Oferrtálerová, M.; Miklósová, V. The institutional tools of integrated landscape management in Slovakia for mitigation of climate change and other natural disasters. Eur. Countrys. 2017, 9, 647-657. [CrossRef]

32. AGENDA 21. United Nations Conference on Environment and Development. Rio de Janeiro (United Nations), A/Conf. 15l/4; 1992. Available online: https://sustainabledevelopment.un.org/ outcomedocuments/agenda21 (accessed on 10 September 2018).

33. Office for Official Publications of the European Communities. European Spatial Development Perspective ESDP. Towards Balanced and Sustainable Development of the Territory of the EU; Office for Official Publications of the European Communities: Luxembourg, 1999; ISBN 92-828-7658-6.

34. Directive of the 2000/60/EC of the European Parliament and of the Council-Water Framework Directive. 2000. Available online: http:/ / data.europa.eu/eli/dir/2000/60/oj (accessed on 10 September 2018).

35. Council of Europe. European Landscape Convention; Council of Europe: Florence, Italy, 2000.

36. United Nations. United Nations Millennium Declaration. Resolution Adopted by the General Assembly; A/55/L.2; United Nations: New York, NY, USA, 2000.

37. Economic Comission for Europe. Spatial Planning: Key Instrument for Development and Effective Governance with Special Reference to Countries in Transition; ECE/HBP/146; UN Publication, Economic Comission for Europe: Geneva, Switzerland, 2008.

38. United Nations. Transforming Our World: The 2030 Agenda for Sustainable Development; United Nations: New York, NY, USA, 2015; Available online: http:/ / www.un.org/ga/search/view_doc.asp?symbol=A/RES/70/ $1 \&$ Lang=E (accessed on 10 September 2018).

39. Bezák, P. Integrated approach to the evaluation landscape on the example of research in National Park Poloniny. In Integrated Landscape Management_Basic Tool of the Implementation of the Sustainable Development; Izakovičová, Z., Ed.; Slovak Academy of Sciences, Ministry of the Environment: Bratislava, Slovakia, 2006; pp. 125-130.

40. Cairns, J., Jr.; Crawford, T.V.; Salwasser, H. (Eds.) Implementing Integrated Environmental Management; Virginia Polytechnic Institute and State University: Blacksburg, VA, USA, 1994; p. 137.

41. Ružička, M.; Miklós, L. Basic premises and methods in landscape-ecological planning and optimisation. In Changing Landscapes: An Ecological Perspectives; Zonnenveld, I.S., Forman, R.T.T., Eds.; Springer: New York, NY, USA, 1990; pp. 233-260.

42. Bezák, P.; Mederly, P.; Izakovičová, Z.; Špulerová, J.; Schleyer, C. Divergence and conflicts in landscape planning across spatial scales in Slovakia: An opportunity for an ecosystem services-based approach? Int. J. Biodivers. Sci. Ecosyst. Serv. Manag. 2017, 13, 119-135. [CrossRef]

43. Miklós, L.; Kočická, E.; Diviaková, A.; Belaňová, E. Integrated Landscape Management. Institutional Tools; VKÚ. a.s.: Harmanec, Slovakia, 2011; p. 196. 
44. Estrada-Carmona, N.; Hart, A.K.; DeClerck, F.A.J.; Harvey, C.A.; Milder, J.C. Integrated landscape management for agriculture, rural livelihoods, and ecosystem conservation: An assessment of experience from Latin America and the Caribbean. Landsc. Urban Plan. 2014, 129, 1-11. [CrossRef]

45. García-Martín, M.; Bieling, C.; Hart, A.; Plieninger, T. Integrated landscape initiatives in Europe: Multi-sector collaboration in multi-functional landscapes. Land Use Policy 2016, 58, 43-53. [CrossRef]

46. Milder, J.C.; Hart, A.K.; Dobie, P.; Minai, J.; Zaleski, C. Integrated landscape initiatives for African agriculture, development, and conservation: A region-wide assessment. World Dev. 2014, 54, 68-80. [CrossRef]

47. Scherr, S.J.; Heiner, K. Towards an Approach to Integrated Landscape Modeling for the SDGs; EcoAgriculture Partners: Washington, DC, USA, 2016.

48. Scherr, S.J.; Shames, S.; Friedman, R. Defining Integrated Landscape Management for Policy Makers. Ecoagriculture Policy Focus No. 10. 2013. Available online: http://www.un.org/esa/ffd/wp-content/ uploads/sites/2/2015/10/IntegratedLandscapeManagementforPolicymakers_Brief_Final_Oct24_2013_ smallfile.pdf (accessed on 11 September 2018).

49. Zanzanaini, C.; Tran, B.T.; Singh, C.; Hart, A.; Milder, J.; DeClerck, F. Integrated landscape initiatives for agriculture, livelihoods and ecosystem conservation: An assessment of experiences from South and Southeast Asia. Landsc. Urban Plan. 2017, 165, 11-21. [CrossRef]

50. Act of the National Council of Slovak Republic No. 237/2000 Coll., Amending and Supplementing the Act No. 50/1976. On Territorial Planning and Building Code (Building Act). Available online: https: / / www.ujd.gov.sk/files/legislativa/145_2010_EN.pdf (accessed on 10 September 2018).

51. UNCCD/Global Land Outlook Working Paper/Integrated Landscape Management. 2017. Available online: https: / www.researchgate.net/publication/320211462 (accessed on 10 September 2018).

52. Kočická, E.; Kočický, D. Database of abiotic complexes as a landscape and ecological basis for integrated landscape management in the Slovak Republic. Acta Fac. Ecol. 2014, 31, 35-50.

53. Belaňová, E.; Kočická, E.; Diviaková, A. Implementation of Integrated Landscape Management Tools at Regional and Local Level; Vydavatel'stvo Technickej Univerzity vo Zvolene: Zvolen, Slovakia, 2014; p. 117.

54. Grunewald, K.; Bastian, O. Special issue: "Maintaining Ecosystem Services to Support Urban Needs". Sustainability 2017, 9, 1647. [CrossRef]

55. Antrop, M.; Van Eetvelde, V. Landscape Perspectives the Holistic Nature of Landscape (Landscape Series 23); Springer: Dordrecht, The Netherlands, 2017; p. 436, ISBN 9789402411812.

56. Naveh, Z.; Lieberman, A.S. Landscape Ecology Theory and Applications, 2nd ed.; Springer: New York, NY, USA, 1993; p. 360.

57. Mezősi, G.; Blanka, V.; Bata, T.; Ladanyi, Z.; Kemeny, G.; Meyer, B.C. Assessment of future scenarios for wind erosion sensitivity changes based on ALADIN and REMO regional climate model simulation data. Open Geosci. 2016, 8, 465-477. [CrossRef]

58. Izakovičová, Z. Evaluation of the anthropogenic change of the landscape structure. Ekológia 1997, 16, 73-80.

59. Haines-Young, R.; Potschin, M. Common International Classification of Ecosystem Services (CICES) Consultation on Version 4, August-December 2012. Available online: https://unstats.un.org/unsd/ envaccounting/seearev/GCComments /CICES_Report.pdf (accessed on 10 September 2018).

60. Izakovičová, Z.; Oszlányi, J. The impact of stress factors, landscape loads and human activities: Implications for sustainable development. Int. J. Environ. Waste Manag. 2013, 11, 111-128. [CrossRef]

61. Chavez-Tafur, J.; Zagt, R.J. (Eds.) Towards Productive Landscapes; Tropenbos International: Wageningen, The Netherlands, 2014; Volume 56, p. 246.

62. Sayer, J.A.; Campbell, B. Research to integrate productivity enhancement, environmental protection, and human development. Conserv. Ecol. 2001, 5, 32. [CrossRef]

63. Miklós, L. The concept of the territorial system of ecological stability in Slovakia. In Ecological and Landscape Consequences of Land Use Change in Europe; Jongman, R.H.G., Ed.; ECNC: Tilburg, The Netherlands, 1996; pp. 385-406.

64. Statistic Yearbook of Trnava District, 1st ed.; Úrad Geodézie, Kartografie a Katastra Slovenskej Republiky: Bratislava, Slovakia, 2018; ISBN 978-80-89831-06-7.

65. Slovak Road Administration, 2015, Slovenská Správa Ciest, 2015. Available online: http://www.ssc.sk/ sk/technicke-predpisy-rezortu/databaza-hydroizolacnych-systemov-na-mostoch/3-2015.ssc (accessed on 10 September 2018). 
66. Moyzeová, M.; Miklós, L.; Šatalová, B.; Izakovičová, Z.; Oszlányi, J.; Kenderessy, P.; Štefunková, D.; Krnáčová, Z. Quality of Environment Assessment for Rural Settlements (Example of Trnava District); UKE SAV: Bratislava, Slovakia, 2015; ISBN 978-80-89325-26-9.

67. Čurlík, J.; Šefčík, P.; Jambor, P. Geochemical Atlas of the Slovak Republic. Part V, Soils; Ministry of the Environment of the Slovak Republic: Bratislava, Slovakia, 1999; ISBN 80-88833-14-0.

68. Maňkovská, B.; Izakovičová, Z.; Oszlányi, J.; Frontasyeva, M. Temporal and spatial trends (1990-2010) of heavy metal accumulation in mosses in Slovakia. Boil. Divers. Conserv. 2017, 10, 28-32.

69. Bezák, P.; Izakovičová, Z.; Miklós, L. Representative Types of Slovak Landscape; ÚKE SAV: Bratislava, Slovakia, 2010; p. 165.

70. Izakovičová, Z.; Miklós, L.; Moyzeová, M.; Špilárová, I.; Kočický, D.; Halada, L.; Gajdoš, P.; Špulerová, J.; Baránková, Z.; Štefunková, D. Model of Representative Geo-Ecosystems on Regional Level; ÚKE SAV: Bratislava, Slovakia, 2011; p. 88.

71. Miklós, L.; Izakovičová, Z.; Kanka, R.; Ivanič, B.; Kočický, D.; Špinerová, A.; David, S.; Piscová, V.; Štefunková, D.; Oszlányi, J. Geographic Information System of Ipel Basin; Slovak Academy of Sciences: Zvolen, Slovakia, 2011; p. 43.

72. Dobrucká, A.; Mederly, P. Territorial System of Ecological Stability of Trnava Town-Actualisation; Atelier Dobrucka Ltd. Regioplan: Nitra, Slovakia, 2009; p. 366.

73. Mederly, P.; Bezák, P.; Izakovičová, Z. Ecosystem services assessment methods—Examples and perspectives for planning and decision making. In Flows, Spaces and Societies in Central Europe; Comenius University: Bratislava, Slovakia, 2017; p. 62, ISBN 978-80-223-4350-3.

74. Water Management in the Slovak Republic in 2012. Available online: http:/ / www.vuvh.sk/Documents / vodne_hospodarstvo/MS2014EN.pdf (accessed on 10 September 2018).

75. Hrnčiarová, T.; Kenderessy, P.; Špulerová, J.; Vlachovičová, M.; Piscová, V.; Dobrovodská, M. Status and outlook of hiking trails in the central part of the Low Tatra Mountains in Slovakia between 1980-1981 and 2013-2014. J. Mt. Sci. 2018, 15, 1615-1632. [CrossRef]

76. National Agriculture and Food Center. Available online: http://www.vupop.sk/eng/index.php (accessed on 5 June 2018).

77. Enviroportal of the Slovak Republic. Available online: https://www.enviroportal.sk/ (accessed on 30 July 2017).

78. Šveda, M.; Vigašová, D. Land use changes in the hinterland of major Slovak cities. Geografie 2010, 115, 413-439. (In Slovak)

79. Agency for Nature Conservation and Landscape Protection of the Czech Republic. Available online: http: / / www.ochranaprirody.cz/en/ (accessed on 10 September 2018).

80. Moyzeová, M. Territorial development and social relationships. Ekologické Štúd. 2017, 8, 69-76.

81. Environmental Status Report of Trnava District. 2002. Available online: https://www.enviroportal.sk/ uploads/report/ktt02s.pdf (accessed on 10 September 2018).

82. Izakovičová, Z.; Špulerová, J.; Petrovič, F. Integrated approach to sustainable land use management. Environ. Open Access J. Environ. Conserv. Technol. 2018, 5, 37. [CrossRef]

83. Leadley, P.; Pereira, H.M.; Alkemade, R.; Fernandez-Manjarrés, J.F.; Proença, V.; Scharlemann, J.P.W.; Walpole, M.J. Biodiversity Scenarios: Projections of 21st Century Change. In Biodiversity and Associated Ecosystem Services; Technical Series No. 50; Secretariat of the Convention on Biological Diversity: Montreal, QC, Canada, 2010; p. 132.

84. IEEP; Alterra; Ecologic; PBL; UNEP-WCMC. Scenarios and Models for Exploring Future Trends of Biodiversity and Ecosystem Services Changes; Institute for European Environmental Policy, Alterra Wageningen UR, Ecologic, Netherlands Environmental Assessment Agency, United Nations Environment Programme World Conservation Monitoring Centre: Wageningen, The Netherlands, 2009.

85. Sachs, J.D.; Baillie, J.E.M.; Sutherland, W.J.; Armsworth, P.R.; Ash, N.; Beddington, J.; Blackburn, T.M.; Collen, B.; Gardiner, B.; Gaston, K.J.; et al. Biodiversity Conservation and the Millennium Development Goals. Science 2009, 325, 1502-1503. [CrossRef] [PubMed]

86. UNDP. Human Development Report 2011, Sustainability and Equity: A Better Future for All; United Nations Development Programme: New York, NY, USA, 2011.

87. CBD, Global Biodiversity Outlook 3. Available online: http://gbo3.cbd.int/ (accessed on 20 December 2010). 
88. EEA. Asessing Biodiversity in Europe-The 2010 Report. 2010. Available online: http:/ / www.eea.europa. eu/publications/assessing-biodiversity-in-europe-84 (accessed on 12 December 2010).

89. FAO_GFRA Global Forest Resource Assessment 2005. FAO Forest Report. Food and Agriculture Organization of the United States, 2006. Available online: http://www.fao.org/DOCREP/008/a0400e/ a0400e00.htm (accessed on 10 September 2008).

90. Mooney, H.; Larigauderie, A.; Cesario, M.; ELmquist, T.; Hoegh-Guldberg, O.; Lavorel, S.; Mace, G.T.; Palmer, M.; Scholes, R.; Yahara, T. Biodiversity, climate change and ecosystem services. Current Opinion in Environmental. Curr. Opin. Environ. Sustain. 2016, 1, 46-54. [CrossRef]

91. Reid, W.V.; Mooney, H.A.; Cropper, A.; Capistrano, D.; Carpenter, S.R.; Chopra, K.; Dasgupta, P.; Dietz, T.; Duraiappah, A.K.; Hassan, R.; et al. Millenium Ecosystem Assesment-Ecosystems and Human Well-Being. Syntheses; Univerzita Karlova v Prahe: Praha, Czech Republic, 2005; p. 138.

92. Sabo, P.; Urban, P.; Turisová, I.; Považan, R.; Herian, K. Threat and Protection of Biodiversity. Selected Chapters of Global Environmental Problems; Centrum Vedy a Výskumu., Inštitút Výskumu Krajiny a Regiónov, Univerzita Mateja Bela v Banskej Bystrici, Katedra Biológie a Ekológie, Fakulta Prírodných vied, Univerzita Mateja Bela v Banskej Bystrici \& Občianske Združenie Živica: Banská Bystrica, Slovakia, 2011; p. 328, ISBN 978-80-968989-6-5.

93. Yafei, L.; Gaohuan, L. Characterizing Spatiotemporal Pattern of Land Use Change and Its Driving Force Based on GIS and Landscape Analysis Techniques in Tianjin during 2000-2015. Sustainability 2017, 9, 894. [CrossRef]

94. Kopecká, M.; Rosina, K. Identification of changes in urbanized landscape based on VHR satellite data: Study area of Trnava (in Slovak). Geogr. Čas. 2014, 66, 247-267.

95. Izakovičová, Z.; Bezák, P.; Mederly, P. Implementing ecosystem services in planning and decision-making. In Gospodarka Przestrzenna, Stan Obecny i Wyzwania Przyszłości-Ujęcie Interdyscyplinarne; Uniwersytet Przyrodniczy we Wrocławiu: Wrocław, Poland, 2017; pp. 18-19.

96. Izakovičová, Z.; Považan, R. Increasing pressure on ecosystems. In Global Megatrends: Evaluation and Challenges from the Perspective of the Slovak Republic; Centrum Spoločenských a Psychologických Vied, SAV: Staré Mesto-Bratislava, Slovakia, 2016; p. 327.

97. Izakovičová, Z.; Moyzeová, M.; Oszlányi, J. Problems in Agricultural Landscape Management Arising from Conflicts of Interest-A Study in the Trnava Region, Slovak Republic. In Innovations in European Rural Landscapes; Wiggering, H., Ende, H.P., Knierim, A., Pintar, M., Eds.; Springer: Berlin/Heidelberg, Germany, 2010; pp. 77-95.

98. Aurex. Territorial Plan of the Region Trnava. Self-Governing Region. Directional Part; TTSK: Trnava, Slovakia, 2014; p. 387.

99. Muchová, Z.; Jusková, K. Stakeholders' perception of defragmentation of new plots in a land consolidation project: Given the surprisingly different Slovak and Czech approaches. Land Use Policy 2017, 6, 356-363. [CrossRef]

100. Pauditšová, E.; Slabeciusova, B. Modelling as a Platform for Landscape Planning. In Geoconference on Informatics. Geoinformatics and Remote Sensing; Stef92 Technology Ltd.: Sofia, Bulgaria, 2014; Volume III, pp. 753-760.

101. Muchova, Z.; Leitmanova, M.; Petrovic, F. Possibilities of optimal land use as a consequence of lessons learned from land consolidation projects (Slovakia). Ecol. Eng. 2016, 90, 294-306. [CrossRef]

102. Atlas of Slovak Landscape; MŽP SR, Bratislava, SAŽP: Banská Bystrica, Slovakia, 2002; p. 344, ISBN 80-88833-27-2.

103. Poudevigne, I.; Alard, D. Agricultural landscape dynamic: A case study in the Odessa region, the Ukraine and comparative analysis with the Brionne basin case study France. Ekológia 1997, 16, 295-308.

104. Matlovič, R. Transformation processes and their effects in intra-urban structures of post-communist cities (in Slovak). Acta Fac. Rerum Nat. Univ. Matthiae Belii 2001, 8, 73-81.

105. Sýkora, L. Changes in the internal spatial structure of post-communist Prague. GeoJournal 1999, 49, 79-89. [CrossRef]

106. Hirt, S. Landscapes of post-modernity: Changes in the built fabric of Belgrade and Sofia since the end of socialism. Urban Geogr. 2008, 29, 785-809. [CrossRef] 
107. Medvedkov, Y.; Medvedkov, O. Upscale housing in post-Soviet Moscow and its environs. In The Post-Socialist City: Urban Form and Space Transformations in Central and Eastern Europe after Socialism; Stanilov, K., Ed.; Springer: Dordrecht, The Netherlands, 2007; pp. 245-265.

108. Feldman, M. Urban waterfront regeneration and local governance in Tallinn. Eur. Asia Stud. 2000, 52, 829-850. [CrossRef]

109. Kiss, E. Spatial impacts of post-socialist industrial transformation in the major Hungarian cities. Eur. Urban Reg. Stud. 2004, 11, 81-87. [CrossRef]

110. Sýkora, L.; Bouzarowski, S. Multiple Transformations: Conceptualising the Post-communist Urban Transition. Urban Stud. 2011, 49, 1-18. [CrossRef]

111. Temelová, J.; Novák, J. From industrial neighbourhood to modern urban centre: Transformation in physical and functional environment of central Smíchov. Geogr-Sb. CGS 2007, 112, 315-333.

112. Sýkora, L. Gentrification in post-communist cities. In The New Urban Colonialism: Gentrification in a Global Context; Atkinson, R., Bridge, G., Eds.; Routledge: London, UK, 2005; pp. 90-105.

113. Forman, R.T.T.; Godron, M. Landscape Ecology; John Wiley and Sons: New York, NY, USA, 1986; p. 619.

114. Mander, Ü.; Murka, M. Landscape coherence: A new criterion for evaluating impacts of land use changes. In Multifunctional Landscapes. Vol. III-Continuity and Change; Mander, Ü., Antrop, M., Eds.; WIT Press: Southampton, UK, 2003; pp. 15-32.

115. Pauleit, S.; Ennos, R.; Golding, Y. Modelling the environmental impacts of urban land use and land cover change-A study in Merseyside, UK. Landsc. Urban Plan. 2005, 71, 295-310. [CrossRef]

116. Haase, D.; Frantzeskaki, N.; Elmqvist, T. Ecosystem services in urban landscape. Practical applications and governance implications. Ambio 2014, 43, 407-412. [CrossRef] [PubMed]

117. Haase, D.; Kabisch, N.; Haase, A. Endless Urban Growth? On the Mismatch of Population, Household and Urban Land Area Growth and Its Effects on the Urban Debate. PLoS ONE 2013, 8, e66531. [CrossRef] [PubMed]

118. Albert, C.; Aronson, J.; Fürst, C.; Opdam, P. Integrating ecosystem services in landscape planning: Requirements, approaches, and impacts. Landsc. Ecol. 2014, 29, 1277-1285. [CrossRef]

119. Haase, D.; Haase, A.; Kabisch, N.; Kabisch, S.; Rink, D. Actors and factors in land-use simulation: The challenge of urban shrinkage. Environ. Model. Softw. 2012, 35, 92-103. [CrossRef]

120. Fei, Z.H.; Johnson, C.V. Assessment of Land-Cover/Land-Use Change and Landscape Patterns in the Two National Nature Reserves of Ebinur Lake Watershed, Xinjiang, China. Sustainability 2017, 9, 1553. [CrossRef]

121. Bičík, I.; Jeleček, L.; Štěpánek, V. Land-Use Changes and their Social Driving Forces in Czech in the 19th and 20th Centuries. Land Use Policy 2001, 18, 65-73. [CrossRef]

122. Mendel, M. Residential developers and investors in Central Europe: Boom and bust. Monu Mag. Urban. 2010, 12, 23-30.

123. Václavík, T.; Rogan, J. Identifying Trends in Land Use/Land Cover Changes in the Context of Post-Socialist Transformation in Central Europe: A Case Study of the Greater Olomouc Region. GISci. Remote. Sens. 2006, 46, 54-76. [CrossRef]

124. Nuissl, H.; Haase, D.; Wittmer, H.; Lanzendorf, M. Environmental impact assessment of urban land use transitions-A context-sensitive approach. Land Use Policy 2009, 26, 414-424. [CrossRef]

125. Bariski, J. The consequences of changes of ownership for agricultural land use in Central European countries following the collapse of the Eastern Bloc. Land Use Policy 2017, 66, 120-130.

126. Sroka, W.; Mikolajczyk, J.; Wojewodzic, T.; Kwoczynska, B. Agricultural Land vs. Urbanisation in Chosen Polish Metropolitan Areas: A Spatial Analysis Based on Regression Trees. Sustainability 2018, 10, 837. [CrossRef]

127. Muchová, Z.; Hrnčiarová, T.; Petrovič, F. Local Territorial System of Ecological Stability for Land Consolidation; Slovenská Polnohospodárska Univerzita v Nitre: Nitra, Slovakia, 2013; p. 87, ISBN 978-80-552-1127-5.

128. Izakovičová, Z.; Bezák, P.; Mederly, P.; Špulerová, J. Implementation of the ecosystem services concept in planning and management practice in the Slovak Republic-Results of the Open NESS project in Trnava case study. In Životné Prostredie; Institute of Landscape Ecology of Slovak Academy of Sciences: Bratislava, Slovakia, 2017; pp. 198-204. ISSN 0044-4863.

129. Huang, D.; Jin, H.; Zhao, X.; Liu, S. Factors influencing the conversion of arable land to urban use and policy implications in Beijing, China. Sustainability 2015, 7, 180-194. [CrossRef] 
130. Mazzocchi, C.; Sali, G.; Corsi, S. Land use conversion in metropolitan areas and the permanence of agriculture: Sensitivity Index of Agricultural Land (SIAL), a tool for territorial analysis. Land Use Policy 2013, 35, 155-162. [CrossRef]

131. Deng, X.; Huang, J.; Rozelle, S.; Zhang, J.; Li, Z. Impact of urbanization on cultivated land changes in China. Land Use Policy 2015, 45, 1-7. [CrossRef] 